\title{
The Criminal Liability of Parent Corporations for Acts of Its Subsidiaries under Criminal Law in Jordan: A Comparative Study*
}

\author{
Raed S. A. Faqir" \\ Zarqa University College, Al-Balqa' Applied University (BAU), Zarqa, Jordon \\ Email: fageerjo@yahoo.com, faqirreaed@g.mail.com
}

Received 14 June 2016; accepted 29 August 2016; published 2 September 2016

Copyright @ 2016 by author and Scientific Research Publishing Inc.

This work is licensed under the Creative Commons Attribution International License (CC BY).

http://creativecommons.org/licenses/by/4.0/

(c) (i) Open Access

\section{Abstract}

The present study deals with many legal aspects of criminal liability of legal entities, as well tries to explain the legislative and judicial attitude towards this sort of liability. The current research examines laws on criminal liability of parent companies for illegal acts of the subsidiary under criminal legislation in Jordan, and discerns legal norms and applicable aspects related to the doctrine of corporate criminal liability and the legal relationship of the parent company with the subsidiary. This study will first conduct a comprehensive analysis of the provisions of the Jordanian Company Law on the relationship between the parent company and the subsidiary. Issues of corporate criminal liability under the Jordanian legal and other selective comparative legal systems, several aspects of legal systems of common law and civil law about the criminal liability of parent corporations for conduct of parties outside of organization, or for offences of dissolved corporations, or for offences of predecessor's corporations will be discussed. On the light of secrecy of studies in the direct theme of the present study and ambiguity of regulatory and legal framework in this topic, the researcher will carry out the analysis of the related legislation, including criminal laws merely with respect to the criminal liability of corporation for offences committed by its subsidiaries in order to revamp the legal framework of this issue. An attempt will take into consideration both national and international legal attitudes towards the theme of this research at national and international levels. Finally, this study is a bold step for the detection of weaknesses in the Jordanian legislation in regulating this matter, which is necessary for the interest of the national economy and to protect companies, corporation, economic units and their shareholders, and to create an attractive investment environment for investors.

\footnotetext{
*This work has been carried out during sabbatical leave granted to the author (Raed S. A. Faqir) from Al-Balqa' Applied University (BAU) during the academic year 2015/2016.

\#Associated professor in law.
} 


\section{Keywords}

\section{Corporate Liability, Parent-Subsidiary Relationship, Criminal Law, Jordan}

\section{Introduction}

The principle of corporate criminal liability, in general, was one of the most disputed subject in the end of the last century, especially when the crimes of legal entities became a real threat to the environmental, economic, social, financial and personal security of the societies in Europe, America and the Asia, etc. Globalization and the revolution of technology and communication have negatively contributed to the criminal phenomenon of corporations. Some of the activities of corporations can be very harmful to an economy, for example if they result in pollution or personal injury or undermine confidence in the operation of financial markets. The overseas companies and parent holding companies and their subsidiaries have nationally and internationally involved in several criminal activities, such as fraud, bribery, food adulteration, antitrust, financial offenses, environmental crimes and worker death, etc.

The concept of criminal liability of parent companies for illegal acts of the subsidiary is a disputed issue in the common law and civil law countries. However, the principle of corporate criminal liability, in general, has changed over the years; as nowadays corporate criminal liability is recognized in different systems of the world, especially in those countries a corporate criminal liability is adopted as an integral part of its criminal laws. In a non-criminal liability model, corporations are not integral part of criminal law, and the countries of this model have developed a deliberate administrative sanctions system that includes provisions on corporate criminal liability. The corporate criminal liability model that is adopted in some of common law and civil law countries, including Jordan encourages legal entities to activate the systems of controlling and supervising over its human persons, and to ensure that all activities of corporation are achieved in respect to the rules and provisions of law and within legal boundaries. In present, the crimes of corporate entities are more serious than the crimes committed by human persons, such as trafficking in human beings, money laundering, financial crimes, industrial and commercial fraud, tax and customs evasion, and other unlimited types of economic, financial and moral crimes.

The criminality of parent corporations and subsidiaries faced a global reaction through the creation of legal and judicial regimes that could persecute and punish liable legal entities for the crimes committed by their natural persons and their subsidiaries in order to deter corporate wrongdoing. The purpose of making corporations potentially criminally liable for harmful activity is to encourage them to take all cost-justified measures to prevent harm occurring, particularly where the harm might be small for a particular individual but spread across a wide number of victims or where victims would not by themselves have sufficient resources to bring private actions against corporations.

Corporate liability was equally recognized under penal, administrative and civil legislations. In present, most of the global legal systems accept that legal entities can be punished with civil and administrative sanctions. However, the principle of corporate criminal liability is still a disputed topic, as several jurisdictions accepted and applied it, while other systems rejected it.

The principle of criminal liability of parent companies for illegal acts of the subsidiary has different positions under the world legal systems. Nationally, the principle is influenced with many indigenous historical, political and economic circumstances, for this reason the legal and judicial reaction against corporate crimes and criminality differs from one country to another. The similarity between two Jurisdictions of common law and civil law is that the corporate criminality is based on the enforcement of individual liability for illegal acts of the legal entity. Therefore, the corporate human individuals, such as directors, representatives, officers and the employees can be criminally held liable for corporate crimes.

The Criminal liability model is adopted in many countries of civil law jurisdictions, such as France and Jordan, as well as in common law countries like USA and Canada, as corporations are criminally liable and punishable for the crimes that committed in their names and benefits by natural persons employed in a corporation. The relationship between the parent company and the subsidiary exists under this model on the basis of financial and management unity, and sometimes on the basis of organic theory, therefore the general rule of corporate liability is applied on the parent-subsidiary crimes. The criminal liability of a corporation for conduct of parties outside of organization, or for offences of dissolved corporations, and or for offences of predecessor's corporations has several treatments in the countries of the criminal liability model. 
On the other side, there is a non-criminal liability model, which exists in Germany, Italy and some of Arab countries such Algeria, Egypt, Libya and Kuwait. This model assumes the corporate administrative and civil liability, and corporation cannot be criminally held liable for the crimes of their natural person, because the criminal liability of corporation still is not recognized in the criminal laws of these countries. Therefore, parent companies can be administratively and civilly, but not criminally liable for acts of their subsidiaries. Moreover, the criminal liability of a corporation for conduct of parties outside of organization, or for offences of dissolved corporations, and or for offences of predecessor's corporations does not exist under this model.

\subsection{Problem of Research}

The principle of corporate criminal liability is recognized under the Jordanian criminal law, but this law does not expressly contain any special provisions about the criminal liability of Parent Corporation for crimes of the subsidiary. Thus, can the general rules of section 74 of the Jordanian penal Code be applied to parent corporations for crimes of the subsidiary?

\subsection{Statement of Problem}

The present study is devoted to ascertain the extent of the discretionary powers of the judge in the application of corporate criminal liability and imposing sanctions in the light of what is stipulated in section 74 of the Penal, and determining the legal mechanism to investigate and prosecute crimes committed by corporation and its subsidiaries under Jordanian legal system and comparative laws, as well as the need for a reform of the existing legal and regulatory regime surrounding those issues. The central research questions of this study are as following:

- What are the characters and limitations of the relationship between the parent company and the subsidiary?

- Is the form of corporate criminal liability, which is adopted by the Jordanian legal system differs from other models adopted by other legal systems in the world?

- How different legal systems of common law and civil law do with the subject of criminal liability of parent corporations in both national and international levels?

- Can a corporation be criminally liable for conduct of parties outside of organization, or for offences of dissolved corporations, and or for offences of predecessor's corporations?

\subsection{Research Aims and Objectives}

The main objectives of this research are as following:

1) To ascertain the extent (if any) to which criminal law holds corporations liable for acts of the subsidiary in Jordan and other countries.

2) To identify the relationship between the parent company and the subsidiary.

3) To delve to judicial and legal instruments of criminal liability of parent corporations in both national and international levels.

4) To analyze the legal aspects of corporate liability based on conduct of parties outside of organization, criminal liability for offences of dissolved corporations, and criminal liability for offences of predecessor's corporations.

\subsection{Scope and Limitation of Research}

This study will examine the criminal liability of Parent Corporation for crimes of the subsidiary within the Jordanian jurisprudence. It will analyze the law on corporate criminal liability in Jordan, and other countries. Consequently, the study will explore the relationship between the parent company and the subsidiary, criminal liability of parent corporations in both national and international levels, corporate liability based on conduct of parties outside of organization, criminal liability for offences of dissolved corporations, and criminal liability for offences of predecessor's corporations. An analysis will be made on the Jordanian criminal and commercial laws and other comparative statutes and case laws as well as assess the legislations and the efficiency or otherwise from other jurisdictions. The study concludes and explores how the comparative approaches may offer lessons for Jordan.

\subsection{Significance and Benefits of the Research}

The present study delves the issue of legal relationship between the corporation and its organs, agents, em- 
ployees, independents contractors and subsidiaries on the bases of agency and organic theories. The complexity is always about the relationship between the corporations as a fiction person with their corporate subsidiaries; therefore, the present study contributes to clarify all legal issues related to corporate criminal liability of a parent corporation for the acts of its subsidiary.

\subsection{Research Methodology}

The methodology adopted in the current research is doctrinal, which emphasizes the legal propositions and doctrines. This methodology is founded upon the analytical, critical and comparative study of statutes, its interrelationship and interpretation of statutes made by the judiciary. On the same context, the research is conducted through investigating and using secondary sources includes books, review of case law, statutes, international treaties, articles and journals. Material collection shall include intensive library research and internet searches.

\section{Parent Company-Subsidiary's Legal Relationship}

The idea of establishing holding parent companies is new phenomena in the developing countries; even most of Arab legal systems do not deal with this issue. Some of Arab countries accept the concept of a corporate criminal liability as general rule, while other countries refuse it and the criminal liability of parent company for acts of its subsidiary is often subjected to the positive or negative general rule of those systems.

\subsection{Legal Nature of the Parent Company and the Subsidiary}

Some of the countries that have adopted the criminal liability of parent companies for offenses committed by its subsidiary provide wide scope of corporate prosecution and convections and others do not provide restrictive system of prosecuting and convicting of the corporation engaged with a crime. That might be for many reasons, either being historical, political, economic or social. In this section, there many issues to be treated in order to understand the relationship between the parent company and its subsidiaries.

\subsubsection{Concept of the Parent Company}

At present, there is no a comprehensive and uniform definition of the concept of "parent or subsidiary" corporations or groups of firms (Werlauff, 2003: p. 456). However, the concept of "Parent Company" is often known as a holding corporate or sometimes a company identity holder (Chertier, 2015), i.e. a name given by investors to specific companies to identify them at time of investing of purchasing, such as Arab Bank, City Bank of India, Ford Motors, or IBM, etc. The concept of a parent company is distinguished from one to another jurisdiction, with the term normally being stated by way of national legislations deal with corporations and companies in different jurisdictions. Some consider a holding parent company as the company that holds enough shares in other companies for the purpose of influencing the decisions of these companies (Gajewski, 2012: p. 76). Others define the concept of holding parent company as a company that is controlled by another entity, regardless of the method of control.

Despite the national definition of the concept may sound not identical, but still it is useful in case of the absence of the unified general definition of the concept, as most of the indignities legislations of States presumed that the parent company exercises control over the subsidiary ${ }^{1}$. Generally, the corporate parent is realized as a holding company, because such company establishes one or more other companies which are subjected to its control. The controlled company or subsidiary or sister companies are usually under the control of the parent company or holding company. The parent company may have controlling over its subsidiary by owning large parentage of its capital, by which may direct the subsidiary is directed for satisfying the interests of a holding or parent company (Muhammady, 2000: p. 32).

In a legal meaning, holding company is the capital connections that permit a parent company to control and force the subsidiary's acts and decisions in a general sense and influencing the staffing of its subsidiary (Szumański, 1996). Under Jordanian Companies Act, 1997 the holding is defined as: the company holds controlling over its subsidiary by owning $50 \%$ of voting stocks, and forming the subsidiary's management board of

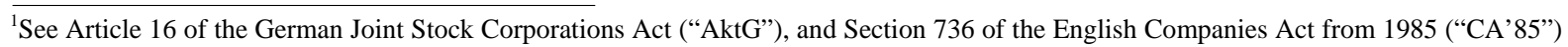
and Article L233-1 of the French Code de Commerce (“CC”). 
directors ${ }^{2}$.

Basically, the Parent Company is a holding corporation; it operates as a joint stock company of capital type. The term of "Parent Company" is defined in section 736 (a) of the English law of 1989, as a company holds a "controlling stake" in a corporation-a holding of over $50 \%$ of the stock-is in effect the de facto parent company of the firm, by which it has material influence over the subsidiary's operations (Spencer, 2004: p. 3). The holding company can be "any company, incorporated or unincorporated, which is in a position to control, or materially to influence, the management of one or more other companies by virtue, in part at least, of its ownership of securities in the other company or companies" (Bonbright \& Means, 1969). The term refers also to "a type of business organization that allows a firm (called parent) and its directors to control or influence other firms called subsidiaries” (Augustus \& Erlinda, 2009: p. 1).

Under English legal jurisprudence the controlled company is defined as a "held company" and a tending subsidiary of the parent company. In Australia, the definition of parent company is defined under section 46 of Corporation Act as a body of corporate "first body" which forms another body corporate called subsidiary, and the parent company controls the composition of subsidiary's board, the casting in a general meeting and holds more than one-half of the subsidiary's stocks. The term of subsidiary company also is defined under Section 5(1) of the Singaporean Companies Act as: a controlled company by another company, which is known as "Parent Company" that have control over the composition of board of directors, power of voting, hegemony on capital shares of the subsidiary.

A significant feature of the holding parent company that differentiates it from analogous types is the reality that the parent business does not scuttle the business itself; it only embraces shares in subsidiaries and uses its rights on these grounds (Koessler, 1949). In brief, the elements of the definition of the parent company under the Company Act of Jordan can be understood as a parent company, one company or group of companies (subsidiaries), controlling large scale percentage of the subsidiaries by the parent company, the existence of separate legal personalities of the controlled companies.

\subsubsection{Concept of the Subsidiary}

The subsidiary company can be defined as a company subjected to the financial and management controlling of the holding parent company ${ }^{3}$, as the holding company owns portion of its capital that enables to control the subsidiary decisions (Ismail, 1990: p. 11).

In Jordan, the concept of subsidiary company is not defined under the Companies Act, but it is clarified in the term of its relationship with the holding company in section 204 of the same Act ${ }^{4}$. In U.K, the concept of subsidiary company is defined by section 46 of Corporations Law as (Ramsay, 1994: p. 544): "a company to be a subsidiary of another company if that other company: controls the composition of the board of directors of the subsidiary, if it is in a position to cast, or control the casting of, more than one-half of the maximum number of votes that might be cast at a general meeting of the subsidiary; or holds more than one-half of the issued share capital of the subsidiary". A distinguishing element is the holding of stocks (shares) or, generally, capital relations between the parent company and its subsidiaries (Gajewski, 2012: p. 76).

\subsubsection{Terminological Features of the Parent/Subsidiary}

A subsidiary is a corporation that is exclusively owned or bulkily controlled by parent company, usually holding parent companies control other companies either by forming or purchasing it, but controlling is not the main reason behind having a subsidiary (Hudson, 2016). The parent may form or purchase another company for operating new line of business unrelated to current business i.e. expanding business, or mitigating risks of new busi-

\footnotetext{
${ }^{2}$ See Section 204 (a) (1) and (2) of the Jordanian Company Act, No (22) of 1997 states that: a) A Holding Company is a Public Shareholding Company which has financial and administrative control over one or more Companies called subsidiary companies in one of the following methods: 1 . To acquire more than one half of the Company's share capital and/or 2. To have control over the formation of its Board of Directors.

${ }^{3}$ Section 4 of the Indian companies Act, 1956 defines a subsidiary company. A company is a subsidiary of another if and only if a) That other company controls the composition of its Board of Directors; or b) That other i) Where the first mentioned company is an existing company in respect of which the holders of Preference shares issued before the commencement of this Act have the same voting rights in all respect as the holders of Equity shares exercises or controls more than half of the total voting power of such company. ii) Where the first mentioned company is any other company, holds more than half in nominal value of its Equity share capitals. OR iii) the company is a subsidiary of any company which is that other company's subsidiary.

${ }^{4}$ See Section 204 (a) (1) and (2) of the Jordanian Company Act, No (22) of 1997.
} 
ness, shareholder reasons or shield parent's assets (Huston \& Edwards, 2013: p. 2).

\section{Characters of Controlling:}

The subsidiary is subjected to the financial and management controlling of the parent company, as all aspects of its monetary policies, financing sources, profit distribution, investment and productive plans are made by the parent company (Al Ibrahim, 2007: p. 97). Though the hegemony of the parent company, the subsidiary has its own separate and independent legal personality, which means that the subsidiary is legally separated from its parent company (Ramsay, 1994: p. 520), but this separation or independence is symbolic and it does not exist in the reality.

According to section 204 (a) (1) the corporation would not be classified as a holding parent company-subsidiary relationship if the parent acquires less than one half of the subsidiary's share capital or when it loses its control over the formation of the subsidiary's board of directors and therefore would be outside range of section 204 of the Companies Act. For the purposes of proving the criminal liability of the parent company for offences of its subsidiaries, it is necessary to prove the parent-subsidiaries relationship within the scope of section 204 (a) (1) and (2) of the same Act. The basic purpose of section 204 is to ensure the holding parent company in exercising its reasonable care and diligence over the activities of its subsidiaries. Finally, it can be said that the provisions of section 204 satisfy the efficiency criteria for establishing the criminal liability of the parent for the crimes of its subsidiary entities.

\section{Approaches of Controlling:}

The parent company may control the subsidiary by owning enough subsidiaries' stocks, but the required percentage of ownership for controlling is a controversial matter: One legal trend emphasizes that the subsidiary's controlling requires the parent company to won more than 51\% of the subsidiary's stocks (Ayadhi, 2015: pp. 10-11). This approach exists in English and French laws, and some of the legislations of Arab countries. The other trend ensures that the subsidiary's controlling can be achieved even if the parent company owns less than $50 \%$ of the subsidiary's stocks. This approach is not applied in case of the Jordanian laws (Ismail, 1990: p.15).

The Accounting Standard AASB 1024 define the term "control" as "the capacity of an entity to dominate decision-making, directly or indirectly, in relation to the financial and operating policies of another entity so as to enable that other entity to operate with it in achieving the objectives of the controlling entity" (Farrar, 1987; Ramsay, 1994: p. 544). This definition sounds more effective than the legal meaning of subsidiary controlling in order to avoid the consequences of the deficiency of the legal definition of subsidiary.

\subsection{Holding Parent Company and Business Forms}

Holding company is an incorporated company; it can be either public or proprietary company. It may exercise its activities after the registration in pursuant of the provisions of the Companies Act. This is the situation in Jordan, and holding companies mostly take the proprietary forms. In Jordan, the proprietary holding company is criminal unlimited company, while the public or state holding company is not liable. In practice, there is a kind of convergence among different types of companies; sometimes such agglomeration mixes the concept of holding company with other similar sort of companies. Therefore, it is useful here to remove such agglomeration.

\subsubsection{Partnership and Joint Ventures}

Partnerships can be defined as informal business; they are carried out by group of persons who seek profit. Unlike holding parent company, partnerships are not having their own separate or independent legal personality (Latimer, 2011: p. 19, 130).

Joint ventures differ from holding parent company, and they are similar to partnerships. This for of business is established to undertake some particular task within a limited time (Gibson \& Fraser, 2011: p. 749). Therefore, the joint venture is distinguished from holding parent company, as it is created for an ad hoc purpose. Moreover, this type of business pieces its resources and share profits, but holds its separate identity through the venture initiative (Chella, 2012: p. 24).

\subsubsection{Multinational Corporations}

The concept of multinational projects refers to "business organizations whose activities are located in more than two countries" and "an organizational form that defines foreign direct investment" (Lazarus, 2001). A multina- 
tional business enterprise is known as a commercial transitional companies or a multinational corporation. This type of business exercises multi activities in different countries (Fischer, 1985: p. 515). Hence, huge enterprises are fit for this sort of business corporations, such as extractive activates. Usually, the main headquarter is located in one country, while its partnerships, joint ventures or subsidiaries are operating its activities in several states (Prakash \& Griffin, 2012: p. 4).

Therefore, it can be said that the concept of multinational enterprise is wider than the concept of holding company, the latter is considered as one type or form of the multinational corporations.

\subsubsection{Investment Corporations}

The investment company owns enough stocks of other companies for the purposes of investment rather than controlling (Legum, 2005: p. 4). Hence, this type of business seeks to gain profits and not to control other forms of business or corporations. It differs from the holdings that own less than one half of its subsidiary's stocks for the purpose of malignantly and financially controlling (Al Masada, 2014: p. 112). This business has no legal obligations of supervising or controlling over the affairs of subsidiaries, while the position of the controlling holding company is different, as it is considered liable for the action of its subsidiaries due to the factors of its hegemony over subsidiaries (Burke, 1992: p. 3).

Despite similarities between investment holding company and controlling holding company, the first company is distinguished from the second one. The controlling holding company plays the role of the supervisor and controller for its subsidiaries, while the investment holding company does not play this role. This makes huge deference in terms of legal liability.

\subsubsection{Sister Company}

A sister company is defined as a subsidiary owned by larger company or parent company and it has its own separate legal personality with close affiliations to the holding parent company (Al Ibrahim, 2007: p. 97). This type of business differs from other type of subsidiaries because always has a strong and closed contact with its controlling company (Al Masada, 2014: p. 112). In civil cases, the horizontal liability of sister companies is based upon their strong and closed relationship, and they can be held liable for the actions, debts and liabilities of each other (Kerr, Ogiba, \& Robinson, 2014). Although the alter-ego principle concerns a parent subsidiary relationship (Pleasant, 2013: p. 1), "under the single enterprise rule, liability can be found between sister companies" 5 .

Despite the independent legal personality of the sister company, which means that the sister company as a subsidiary is separated from other sister companies, but its legal liability for acts of other sister company can be established especially when those have same shareholders or board of directors. However, the predominant view sees a holding company as a group of companies with the ability to impose its will by holding sufficient shares (stock) in one company.

\subsubsection{Agreement of Producers}

This type of business is defined a contract between two or more companies, which aims to setup some sort of unified policy or plan in order to achieve the mutual interests of all parties. For example, the companies agree to withdraw kind of unified economic strategies such as pricing, productivity policies.

\subsection{The Parent Company-Subsidiary Company Relationship}

In Jordan, the foundation of governance of the holding or parent company's affairs is clarified by the Companies Act of 2006; section 204 (a) (2) of the Companies Act provides that a holding company determines the membership of the directing board of its subsidiary, paragraph (d) of section 204 express that the holding company act through its representatives who are appointed in the board of directors of its subsidiary as per as the percentage of its shares.

Both the subsidiary's board of directors and the shareholder in general meeting are the "ego" of the holding and parent company, where a parent company cannot act without their acts, they are the will and mind of the parent company.

${ }^{5}$ See Las Palmas Associates v. Las Palmas Center Associates (1991) 235 Cal. App.3d 1220, p. 1249. 


\subsubsection{Legal Personality}

The concept of legal personality is adversarial issue ${ }^{6}$, as there are many theories tried to deal with nature and essences of legal corporate personality. The present legal systems all over the world have been influenced directly or indirectly by those theories on legal personality of corporations. In general, the legal personality of corporate is based on several theoretical approaches: fictional and realistic (Hahlo, 1969: p. 1).

The legal personality of subsidiary company is separated from the legal personality of the parent company. As an incorporated entity, subsidiary's capital is "either fully owned by the parent company or controlled by a company in collaboration with minority local parents", has its own legal personality (European Commission, 2012: p. 1). While branches, agencies and offices are not subsidiaries, therefore they do not have their own independent legal personality (Cazacus, 2015: p. 2) ${ }^{7}$. This approach gained the attention not only legal jurists and practitioners but also sociologists, especially with the failure of the fiction theory to explain the relationship between the law and society on the basis of sociological facts. Finally, the corporate realist paradigm shows that incorporeal corporation is equal to human beings, and a self-determining subject, just as a real natural person, in the eyes of the law.

\subsubsection{Models of Control}

In practice, Matrix Company's structure creates some sorts of complexity among different stakeholders. On this stream the legal analysis of this subject sounds complicated as there are many types of subsidiaries under the world legal systems. In the opinion of Eddy Wymeersch, subsidiaries are not all alike, as he "distinguishes between a $100 \%$ subsidiary, a 51\% subsidiary, a publicly listed subsidiary, companies with a State interest, a subsidiary within a holding, and a subsidiary engaged in the same line of business as the parent” (Wymeersch, 2003: pp. 575-579). In contrary to the interest of the creditor, the mutual interests between the $100 \%$ subsidiary with the parent company are greatly high, while the interest of the minority shareholders in a $51 \%$ subsidiary is at risk. It has to be noted here that the duty of the parent company may increase, when its subsidiary is publicly listed. In a company with a State interest, the interest of both the parent company and its subsidiary, for many reasons may be at stake (Wymeersch, 2003: pp. 575-579, Kukharchuk, 2008: p. 11). In case of the holding parent company, all categories of persons in the subsidiary, including the minority shareholders, creditors, stakeholders and stakeholders are at stake, especially when a parent and its subsidiary are engaged in the same line of business (Kukharchuk, 2008: p. 11).

One of the basic doctrines of the parent company-subsidiary relationship is, notwithstanding the age, type, size or achievement of a wholly operation of the owned subsidiary, it will constantly be responsible at specific level to its parent corporation as its standard stakeholder (O’Mahony, 2004: p. 112). The parent corporation by holding of over $51 \%$ of the subsidiary's stocks or the majority of subsidiary's capital stocks, it will be visited with controlling the power of voting in the meetings of general assemblies, and influencing the subsidiary by electing and dismissing its board of directors ${ }^{8}$, as well as having a hegemony over decision-making in its subsidiary (Al Masada, 2014: p. 115). Parent-subsidiary relationships, therefore, may be directly to headquarters or indirectly via, for instance, through the parent's participation or contribution in its subsidiary at national, regional, or global levels ${ }^{9}$. Inherent to this notion of accountability are terms control and coordination (O’Mahony, 2004: p. 112).

In Jordan, the provisions of Company Act shows clearly that the parent company controls the management and financial affairs of its subsidiary automatically by hold more than 51\% of the stokes, sections 205 and 206 makes it clearly that the management of subsidiary must be one of the principles duties of the holding parent company. Hence, the management controlling over the subsidiary by parent company takes the form of influencing the composition of the board of directors, while the financial controlling can be through owning of more than $51 \%$ of the subsidiary's stocks ${ }^{10}$. The monetary controlling over the subsidiary means that the parent com-

\footnotetext{
${ }^{6}$ Abraham Ayalew, in his thesis titled "criminal liability of bodies corporate" stated that there are about sixteen theories of legal personality that try to explain the nature of the legal personality of a body corporate (Ayalew, 1998).

${ }^{7}$ Company's branches are defined as secondary center of the parent company, with capital that is fully controlled or owned by its parent corporation and has specific economic and legal independence to this corporation.

${ }^{8}$ See section 204 (a) (2) of the Jordanian Companies Act No (22) of 1997.

${ }^{9}$ See sections 205 and 206of the Jordanian Companies Act No (22) of 1997, which emphasize that the management of the subsidiary company as one of the principle aims of the parent.

${ }^{10}$ See section 206 (a) (1) of the Jordanian Companies Act No (22) of 1997.
} 
pany has the power of supervising and controlling its subsidiary, and interfering in subsidiary’s investment and financial policies, setting up its mechanisms and financing sources, as well as deciding the plans of productivity, percentages of profits and money liquidations, policies of distribution and exportation and ultimately controlling the power of financial decision-making of the subsidiary (Kazim, 2007: p. 30).

\subsubsection{Diagnosis of the Parent-Subsidiary Relationship}

Parent or holding company establishes its subsidiary for many reasons. In general, the relationship of parent company and its subsidiary is based on the notion of shareholding. This type of companies mentioned under section 204 (a) of the Jordanian Company Act, 2006 as stock company having both financial and managerial control over its subsidiaries. Hence, it has a vital role making decisions such as the election and appointment of the board of directors in the subsidiary company. However, the subsidiary company remains an independent and separate entity from the parent company.

It can be noted up on the above legal definitions that the holding parent company is having controlling over the composition of the subsidiary's board of directors, more than half of the voting power, and management and financial hegemony in the affairs of its subsidiary. The aspects of parent company's controlling over its subsidiary can be summarized as following:

\begin{tabular}{|c|c|c|}
\hline & Type of Controlling & Parent-Subsidiary Relationship \\
\hline 1 & Casting Control & $\begin{array}{l}\text { The parent company as clarified under the Jordanian legislation is a corporation that owns } 50 \% \text { of } \\
\text { voting stock of its subsidiary, having half of the capital of the subsidiary means owning enough } \\
\text { voting stock. The Jordanian legislature enables the parent company to control operation and } \\
\text { management of the subsidiary by making it owns enough voting stock, as well as it vitally } \\
\text { participates in the election or influence of subsidiary's board of directors. }\end{array}$ \\
\hline 2 & $\begin{array}{l}\text { Management \& Financial } \\
\text { Controlling }\end{array}$ & $\begin{array}{l}\text { The Jordanian legislature ensures the administrative hegemony of the parent over the subsidiary's } \\
\text { management in section } 204 \text { (1) the Company Act, through influencing or electing the board of } \\
\text { directors. }\end{array}$ \\
\hline 3 & Contractual Controlling & $\begin{array}{l}\text { This type of parent company's controlling over its subsidiary is not known under Jordanian } \\
\text { legislation, while it is recognized under English which ensures it in section } 736 \text { as a contractual } \\
\text { agreement between the parent company and the shareholders who own the majority of voting } \\
\text { stocks in the capital of its subsidiary. }\end{array}$ \\
\hline
\end{tabular}

\section{Criminal Liability of Parent Corporations: National and International Scenarios}

The concept of criminal liability of parent company for illegal acts of its subsidiary in civil law jurisdiction differs from common law jurisdiction. In this section the common law and civil law traditions will be examined, and the practice of the concept of criminal liability in Jordan also will be highlighted in comparison with these traditions.

\subsection{Common Law Traditions}

In common law jurisdictions, the concept of criminal liability of corporations was developed despite the legislative and judicial reluctance, but such reluctance was overcame much earlier than civil law systems, may be because of their earlier experiences of industrial revolution. In the USA and UK, the concept was firstly recognized through the context of nonfeasance by quasi-public bodies ${ }^{11}$, and in the middle of the 19th century, this concept was extended to all crimes that need no evidence of criminal intent. It has been rightly stated that the concept was recognized firstly by English courts in early time of 1842, but the concept of criminal liability of legal entities was firstly developed in the USA in $1907^{12}$ and in UK in $1917^{13}$.

\subsubsection{Criminal Liability of Parent Company in the United States}

In US legal system, courts determine criminal liability of corporations irrespective of the existents of the Mens $\boldsymbol{R} \boldsymbol{e} \boldsymbol{a}$ by adopting the doctrine of category offences (Wagner, 1999: p. 3). US courts apply the general doctrine of

\footnotetext{
${ }^{11}$ See People v. Corporation of Albany, XII Wendell 539 (1834).

${ }^{12}$ See New York Central and Hudson River Railroad Co. v. United States 212 US 481, 1909.

${ }^{13}$ See Tesco Supermarkets Ltd v. Nattrass, AC 153, 1972.
} 
respondeat superior, which makes a corporation liable for illegal acts of any of its staffs, especially if they commit an offence within the scope of their employment and with the intent to benefit the company ${ }^{14}$. In Federal level, this general rule is applied to parent companies, which they can be held criminally liable for illegal acts of the subsidiary ${ }^{15}$, while the situation is different in the States level ${ }^{16}$, as some of the states recognize the principle of criminal liability of parent corporation and other reject it ${ }^{17}$.

However, the principle of the corporate criminal liability, as well as the criminal liability of a parent corporation for illegal acts of the subsidiary is controversial issue in USA. There are two contradictory jurisprudential approaches on the issue of the criminal liability of sole or parent corporations:

An approach opposes the principle of corporate criminal liability in general, and the criminal liability of Parent Corporation in specific. The supporters of this approach argue that the corporate criminal liability and punishment is a mistake and inefficient and it should be replaced by civil liability and personal criminal liability of the corporate employees (Weissmann, Ziegler, McLoughlin, \& McFadden, 2008: p. 3). In brief, this approach supports the idea of eliminating or limiting any form of corporate criminal liability. The main hypothesis of their argument is that the legal entity is merely a fiction which cannot be criminally held liable and punishable, and the only innocent employees, shareholders, agents and creditors who will be directly or indirectly be affected from the criminal penalties (De Maglie, 2005: pp. 250-253). According to this approach, merely parent's management and financial controlling over the subsidiary is not sufficient for holding the joint criminal liability of both companies (Doyle, 2013: pp. 2-3).

The opposite approach recognizes the corporate criminal liability, and deals with corporations as legal entities that are separated from their agents, employees and shareholders (Lederman, 2000). Therefore, the supports of this approach insist on the significance of criminal liability of corporations, even the parent corporations have their own assets, as well as their own liabilities for illegal acts of the subsidiary (Tigar, 1990: pp. 227-230).

\subsubsection{Criminal Liability of Parent Company in the United Kingdom}

In Britain, legal entities are artificial bodies of the law and they have same position of human beings in criminal matters, as they are criminally liable for crimes like human persons. ${ }^{18}$ However, the application of the principle of corporate criminal liability in UK is complicated because of the legal personality issue, and this liability can be established upon two theories of agency and Identification (Binning, 2015). The legal system deals with a corporation as a distinct legal entity, and the corporation has its own legal personality separate to those natural persons who act in its name and for its benefit (Celia, 2002: p. 291).

The general rule in UK is that a corporation has its own legal personality which distinguishes it from its employees and subsidiaries (Wanger, 1999: p. 3), and therefore the parent company cannot be criminally responsible for criminal acts of the subsidiary. The problem of establishing the criminal liability of Parent Corporation for illegal acts of the subsidiary or its agents and employees is that "many economic crimes require a mental element (such as an intention to commit an offence) and there is an inherent difficulty in establishing corporate criminal liability for such offences to attribute a human state of mind, such as intention, to a company is conceptually difficult” (Grimes, Niblock, \& Lorna, 2013). Finally, this ambiguity over the corporate criminal liability under English law was mitigated by recognizing corporation criminal liability for certain types of offences such as corporate manslaughter (Corporate Manslaughter and Corporate Homicide Act 2007) and failure to prevent bribery (Bribery Act 2010).

\subsubsection{Criminal Liability of Parent Company in the Canada}

In Canada, the position is described by the datum that the directing mind principle can be founded at an inferior level of the legal entity. In the case of "Dredge \& Dock"19, the Canadian Supreme Court has laid down that a

\footnotetext{
${ }^{14}$ See People v. Corporation of Albany, XII Wendell 539 (1834).

${ }^{15}$ See United States v. Bestfoods, 524 U.S. 51, 62-65 (1998) (federal). tality Corp., 462 F.3d 666, 674 (6th Cir. 2006).

${ }^{18}$ Citizens United v. Federal Election Commission, No. 08-205, 558 U.S. 310 (2010).

${ }^{19}$ See Canadian Dredge \& Dock Co. v. The Queen 1985 CanLII 32, [1985] 1 SCR 662 (23 May 1985).
}

${ }^{16}$ Some of the States do not recognize the criminal liability of the parent company for its subsidiary on the basis of distinct legal personality For example, in the State of California, the laws don't permit the prosecution or convection of a parent company for acts of its subsidiaries, as each of them has its own independent and separate legal personality, while in the State of Colorado, the criminal liability of a parent company for criminal acts of its subsidiary may be established on the basis of strong relationship between two companies. In State of Michigan, the theory or practice of piercing the corporate veil is applied for proving the criminal liability of the parent-subsidiary companies.

${ }^{17}$ See United States v. Wilshire Oil Co, 427 F.2d 969, 974 (10th Cir. 1970) (federal). See also See Southeast Tex. Inns, Inc. v. Prime Hospi- 
corporation has adopted the English principle of Identification for establishing the corporate criminal liability on the basis that liability for acts and mental states of the corporate employees and officers of both lower and higher levels. Latterly, the same court has changed its mood and decided that directing mind principle covers only the acts and mental states of the corporate employees and officers of at higher levels of authority ${ }^{20}$.

In Canada, the general rule is that the mother corporation may be criminally held liable for offences committed by its subsidiaries ${ }^{21}$. The parent criminal liability cannot be established for action of a "bona fide" subsidiary, especial when it operates independently from the parent company such rule was established in Salomon case $\mathrm{e}^{22}$. The criminal liability of holding parent company may be established in some circumstances already provided I section 21 of the Canadian Criminal Code and in some cases when the company decides to "Pierce of the corporal veil” as regard to a specific transaction that is claimed to be crime. ${ }^{23}$

\subsection{Civil Law Traditions}

Historically, the civil legal system was more reluctant to acknowledge the concept of corporate criminal liability in modern age. This attitude was based on many reasons such as legal entities cannot act and be punished. Hence, they cannot be subjects of criminal penalties. Although, this attitude has disappeared by the seventies of the last century, as the outcome of the recognition of the concept of corporate criminal liability all over the civil law countries.

\subsubsection{Criminal Liability of Parent Company in France}

In France, private legal entities may be criminally liable for the illegal acts and crimes committed on their behalf by their legal natural agents, employees and representatives ${ }^{24}$. Those entities may also be convicted and punished for the crimes of their authorized employees acting on behalf of the corporation through an express power of attorney (délégation de pouvoir), especially when the corporation validly delegates its authorities to them (Catargiu, 2013: p. 28). French courts have approached the corporate criminal liability also on the basis of negligence of the corporation, even if the fault cannot be imputed to a manager or an employee to whom the company has delegated powers (Roby, 2013: p. 15).

In France, each the parent company and subsidiary has its own autonomous legal entity (Deckert, 2011: pp. 150-152). However, the criminal liability of the parent company can be established on the ground of the intervention with the subsidiary's affairs ${ }^{25}$, therefore it will be the crime of the subsidiary and not of its parent company, if the crime is committed within the operation and scope of the subsidiary (Clapham, 2008: pp. 913-914). The parent company can be held criminal for offences of its subsidiary, where it can be prosecuted as "organ" or collaborator for.

\subsubsection{Criminal Liability of Parent Company in Germany}

In Germany, corporations are not subjects of criminal law, and only natural persons who can commit a criminal offence (Dubber, 2012). In German criminal Jurisdiction, legal entities lack the criminal liability and they do not have self-capacity to act. Legal entities may be subjected to some sorts of criminal law penalties, such as forfeiture and confiscation. Those sanctions can be imposed on a corporation according to articles 73 and 74 of GCC. The corporation can be penalized with forfeiture for the commission of illegal act or obtaining something as the outcome of the participant's criminal activities. The sanction of confiscation under article 74 of GCC can be imposed on a corporation, as any object used in commission or preparing for the commission of a crime, can be confiscated $^{26}$.

In Germany, the general rule of criminal liability is applied on parent companies. Therefore, a parent compa-

\footnotetext{
${ }^{20}$ See Rhône (The) v. Peter A.B. Widener (The), [1993] 1 S.C.R. 497.

${ }^{21}$ There are many case where can be held liable for the crimes of its subsidiaries under Canada Legislation, see in this regard section 21 of the Canadian Criminal Code.

${ }^{22}$ Salomon V.A. Salomon and Company limited (1987) A.C. 22(H.L.).

${ }^{23}$ Snook V. London and West Riding Investment Ltd., (1967) 2Q. B. 786 (e.g. C.A).

${ }^{24}$ See the first subsection of article 121-2 of the French Penal Code, which provides that "legal persons, with the exclusion of the state, are criminally liable according to the distinctions in arts 121-4 to 121-7 for offences committed on their behalf by their organs or by their representatives".

${ }^{25}$ See article 121 (2) of the French Penal Code, No (647), 2000.

${ }^{26}$ See sections 73 and 74 of the German criminal Code, 1998, Federal Law Gazette 1, p 3322. See also Section 8 (1) of the Economic Offences Act, 1954.
} 
ny cannot be held liable for the acts of its employees and directors, as well as for illegal acts of the subsidiary or independent agents or contractors (Bose, 2011: pp. 227-228). Parent company, like other corporations, can be penalized with some kinds of criminal sanctions of forfeiture and confiscation on the basis of the per-requirements provided by articles 73 and 74 of GCC. Moreover, other kinds of administrative sanctions such as fines, which can be imposed on parent company for illegal acts committed by its own employees, organs, or representatives, or by those committed by the subsidiary's organs and employees ${ }^{27}$.

In Germany, the dissolution of a company is merely a measure and not a sanction. This measure can be activated for both administrative and civil legal purposes. For instance, the parent company can be dissolved for illegal acts of the members of its supervisory or administrative bodies on the grounds provided under article 396 of GSCA. Finally, it can be said the criminal liability of parent company for illegal acts of the subsidiary is still not existed.

\subsubsection{Criminal Liability of Parent Company in Italy}

The concept of corporate liability is recognized in the Italian legal system. However, the nature of corporate liability under Italian legislation is administrative and not criminal ${ }^{28}$, as a corporation can be administratively held liable for illegal acts and offenses committed by its managers, employees for the interest of the corporation (Carla, 2010).

In Italy, the criminal liability of corporations is not recognized for many reasons such as lack of self-capacity to act, lack of criminal capacity and unphysical nature of legal entities, etc. (Fabrizio \& Silvia, 2011: p.72). For those reasons, corporations are not subjected to criminal law, and a corporation, as provided by article 197 of the Italian Criminal Code, can be civilly liable for the crimes committed for its interest through its agents, representative, employees and executives (Fabrizio \& Silvia, 2011: p. 64). Under Italian legal system, the liability of the corporate person is added to the criminal responsibility of top managers and employees, who have committed the illegal act in the interest of the corporation involved. In 2009, the Italian Supreme Court of Cassation stated "the fundamental principle that if the crime committed in the interest or benefit of the entity does not fall within the list set out in the Decree at the moment of execution, the entity cannot be held responsible, even if the crime committed contains in its structure or absorbs the content of other crimes”29.

\subsubsection{Criminal Liability of Parent Company in Arab Countries}

Arab legal systems mostly are influenced by the civil law traditions. Accordingly, the principle of corporate criminal liability is a disputable issue in Arab law jurisdictions; some of the Arab countries entirely adopt the corporate criminal liability with no distinction between private and public legal entities, such Syria ${ }^{30}$ and Lebanon $^{31}$. In the other hand, some of Arab countries accepted this concept by applying the principle of corporate criminal liability only on private legal entities and not on public legal entities such as U.A.E ${ }^{32}$, Jordan ${ }^{33}$, Iraq ${ }^{34}$ and Bahrain $^{35}$. The third category of Arab countries rejected the recognition of the principle of corporate criminal liability with some exceptions as regard financial and economic crimes such as Algeria ${ }^{36}$ and Egypt $^{37}$, Libya $^{38}$ and Kuwait ${ }^{39}$.

The criminal liability of a parent company for the criminal acts of its subsidiary is relying on the general rule adopted in each legal system of Arab countries. In comparison to the situation in Jordan, parent company may

\footnotetext{
${ }^{27}$ See Section 30 of the German Administrative Act, 1969.

${ }^{28}$ See Legislative Decree No. 231 of 8 June 2001, titled "Discipline of the administrative liability of legal persons, companies and associations even not provided with legal personality, pursuant to Article 11 of Law no. 300 of 29 September 2000”.

${ }^{29}$ Italian Supreme Court of Cassation, criminal section II, sentence No. 41488 of 29 September 2009, n. 41488, CED Cassation, 2009. In Fabrizio Cugia di Sant'Orsola and Silvia Giampaolo, Liability of Entities in Italy, p. 70.

${ }^{30}$ See Sections 209 and 302 of the Syrian Penal Code No. (148) of 1949.

${ }^{31}$ See Section 21 (1) of the Lebanese Penal Code No. (340) of 1943.

${ }^{32}$ See Section 65 of the U.A E Federal Penal Code of 1987.

${ }^{33}$ See Section 74 (2) of the Jordanian Penal Code of 1960.

${ }^{34}$ See Section 80 of Iraqi Penal Code No. (111) of 1969.

${ }^{35}$ See Section 21 of Bahraini Law with Respect to Protection of Community Against Terrorist Acts No. (58) of 2006.

${ }^{36}$ See Section 26 of the Algerian Penal Code, No. (66 - 156) of 1966.

${ }^{37}$ See Section 104 of the Egyptian Companies Law No. (26) of 1954 (Abolished).

${ }^{38}$ See Section 26 of the Libyan Commercial Registration Act, No. (23) of 2010.

${ }^{39}$ See Sections 60 and 66 of the Kuwaiti Penal Code No. (16) of 1960.
} 
be liable for the criminal acts of its subsidiary in Syria ${ }^{40}$. Lebanon ${ }^{41}$, Iraq ${ }^{42}$ and Bahrain ${ }^{43}$, while the parent criminal liability for offences of its subsidiary is not applied totally in Algeria ${ }^{44}$, Egypt ${ }^{45}$, Libya ${ }^{46}$, Kuwait ${ }^{47}$ and U.A.E. ${ }^{48}$.

Two types of criminal sanctions of fines and confiscation are common penalties that can be imposed on parent companies and other corporations for crimes committed by their natural persons in countries such as Syria, Lebanon, U.A.E., Jordan, Iraq and Bahrain. In other Arab countries such as Egypt, Algeria, Libya and Kuwait, no criminal punishments are imposed on corporations, including parent companies for criminal offences, while some types of civil and administrative sanctions, precautionary and security measures ${ }^{49}$ closing, police surveillance, confiscation, deprivation from practicing a profession and dismissal ${ }^{50}$ can be imposed as measures and not criminal penalties.

\subsection{Criminal Liability of Parent Company in Jordan}

In Jordanian legal system, the principle of corporate criminal liability is not a disputable issue, as private legal entities have criminal liability. The criminal liability of legal entities is recognized under the Penal Code of Jordan (Al-Mahazneh, 2015: p. 137). Therefore, legal entities like natural persons are objects of the criminal law, and they can be criminally liable for illegal acts and criminal offenses committed by their organs, agents, representatives and employees (Al Sharosh, 2006: p. 75). The Penal Code determines the conditions for establishing the criminal liability and for imposing punishments on corporations that involved with unlawful actions and activities. Section 74 (2) of this Code clearly recognizes the principle of corporate criminal liability ${ }^{51}$.

The Jordanian Cassation Court applied this principle in early sixties of the last century, as the court ruled that the criminal liability can be established against the company as a legal entity ${ }^{52}$. Consequently, the Court also has ruled that criminal liability of the legal entity does not exclude the criminal responsibility of the natural persons that employed by a corporation, and whose crimes committed in the name or on behalf of the corporation ${ }^{53}$. The Court of Cassation held the corporate criminal liability for custom evasion in harmony with section 205 of the Custom Act and section 74 of the Penal Code, $1960^{54}$. In several cases, the Cassation Court of Jordan has clarified that section 74 (1) of the Penal Code contains a general rule, which provides that the criminal liability of a person can be held when a crime proved that it was committed consciously and intentionally, and such person can be prosecuted, convicted and punished for such crime. The court explained the legislative attitude towards the concept of corporate liability out of interpretation of section 74 (2) by assuring that the legal entity has its own will and mind, and it can be prosecuted and convicted for its crimes ${ }^{55}$. The same court has approved the conviction of the legal entity for the crime of issuing a check without balance in accordance with section 421 of the Jordanian Penal Code ${ }^{56}$.

In addition, the recognition of corporate criminal liability under the Penal Code of Jordan does not exclude

\footnotetext{
${ }^{40}$ See Sections 80, 109 and 110 of the Syrian Penal Code No. (148) of 1949.

${ }^{41}$ See Sections 210 (2), 211 (2), 109 and 110of the Lebanese Penal Code No. (340) of 1943.

${ }^{42}$ See Section 80 of Iraqi Penal Code No. (111) of 1969.

${ }^{43}$ See Section 19 of the Bahraini Penal Code, No. (4) of 1982.

${ }^{44}$ The general rule is applied on the parent-subsidiary companies’ liability, as they cannot be held liable for the criminal acts committed by any one of them or by their natural persons.

${ }^{45}$ In Egypt the concept of criminal liability of a parent company for acts of its subsidiary is not applied, as corporations are criminally not liable for acts of corporate human persons.

${ }^{46}$ A Parent Company cannot be held criminally liable for a crime committed within its subsidiaries or by its natural individuals and the general rule is applied in this case.

${ }^{47}$ See Sections 60 and 66 of the Kuwaiti Penal Code No. (16) of 1960.

${ }^{48}$ The parent company may be criminally liable for criminal acts of its subsidiary, if the general of section 65 of the Penal Code is applied, but there is no case for assuring this.

${ }^{49}$ See Section 26 of the Algerian Penal Code, No. (66 - 156) of 1966.

${ }^{50}$ See Sections 60 and 66 of the Kuwaiti Penal Code No. (16) of 1960.

${ }^{51}$ Section 73 (2) of the Jordanian Penal Code, 1960 provides that "Legal entities other than governmental, public and official institutions and bodies, are criminally liable for crimes committed by their representatives or directors or agents in their name or on their behalf”.

${ }^{52}$ See Jordanian Court of Cassation, Case No. (38), Cassation Decision, 1972, Journal of Judiciary, p. 751.

${ }^{53}$ See Jordanian Court of Cassation, Case No. (31), Cassation Decision, 1961, Journal of Judiciary, p. 42.

${ }^{54}$ See Jordanian Court of Cassation, Case No. (1091), Criminal Cassation Decision, 11 November, 2007.

${ }^{55}$ See Jordanian Court of Cassation, Case No. (178), Criminal Cassation Decision, 1985, Journal of Judiciary, p. 976.

${ }^{56}$ See Jordanian Court of Cassation, Case No. (932), Criminal Cassation Decision, 30 November, 2000.
} 
the personal criminal responsibility of the natural persons employed by the corporation ${ }^{57}$. Therefore, the criminal liability of the corporation for illegal acts and criminal offenses of its agents, organs, representatives and employees dose not exempt those natural persons from their personal criminal responsibility for those offenses committed in the name or for the interest of the corporation (Al-Mahazneh, 2015: p. 135). For instance, section 74 (1) of the Jordanian Penal Code, 1960 distinguishes between the corporate criminal liability and the personal criminal liability of natural persons, who can be separately liable for their crimes, even those committed within the scope of their employment in the corporation.

The Penal Code of Jordan obviously determines the conditions for corporate criminal liability. Section 73 of the Code clearly states that the private legal entities can be criminally held liable for crimes committed by their representatives or directors or agents in their name or on their behalf. The provisions of section 74 (1) are applied to both Jordanian and foreign legal entities, such as holding companies and their subsidiaries, limited companies as well joint stock companies, profit and non-profit legal entities, and all juridical persons, excluding governmental bodies (Al Otawer, 2006: p. 359).

Under Jordanian legal system, legal entities of the private law can be criminally held liable for illegal acts and criminal offenses committed in their names or on their behalf by their representatives or directors or agents. Hence, the provisions of section 74 (2) can be interpreted as to include all crimes that committed in the name or on behalf of a corporation by its managing body, authorized employees intentionally or lack of surveillance or control of corporation's representatives or directors or agents (Aldik, 2016: pp. 10-13).

The general rule of section 74 (2) is applied to parent companies, which means that parent companies can be criminally held for crimes of the subsidiary. The crimes of natural persons employed by the subsidiary can be attributed for both the subsidiary and its parent company and if the conditions per-requested by section 74 (1) are available, then the parent company's criminal liability can be established for crimes of the subsidiary. Therefore, all natural persons, under Jordanian legislation, who manage, run, represent or control the corporation, are considered as authorized agents, employees, representatives and organs of the corporation.

The parent company can be criminally liable for many forms of crimes committed by natural persons of the subsidiary, and corporate crime can be defined as a crime committed either by a legal entity or by human persons that may be identified with a juridical person (Al Sharosh, 2006). Therefore, any crime once committed by the directors, representatives or authorized persons on behalf or name of a corporation can be a corporate crime (Al Masada, 2014). It is noteworthy to say that the holding parent company within the provisions of section 204 of the Jordanian Companies Act can be criminally held liable criminal acts of its controlled subsidiary in case of lacking control or insufficient instructions ${ }^{58}$.

The Corporation and its subsidiaries may be involved with many types of corporate crimes and violations already provided under criminal law and other commercial laws, those crimes include requesting or accepting or offering bribes ${ }^{59}$, embezzlement and client fraud ${ }^{60}$, forgery and using of forged documente ${ }^{61}$, missuse of position's authority ${ }^{62}$, white collar crimes of securities fraud ${ }^{63}$, sham offering of shares or corporate bonds or accepting fake subscriptions ${ }^{64}$, misuse of the corporation's book of accounts ${ }^{65}$, issuance of prospectus contains false date or information or commission of these inofrmation ${ }^{66}$, mishandling the money of customers and shareholders ${ }^{67}$, practicing of deception and prohibited acts ${ }^{68}$, manipulation with rates of commissons ${ }^{69}$, negatively in-

\footnotetext{
${ }^{57}$ Section 73 (1) of the Jordanian Penal Code, 1960 provides that "No person shall be sentenced unless he/she commits the act consciously and willfully".

${ }^{58}$ Section 204 (a) (1) (2) of the Jordanian Companies Act, 1997states that: A holding company is a Public Shareholding Company which has financial and administrative control over one or more Companies called subsidiary companies when it acquires more than one half of the Company's share capital and/or controls over the formation of its Board of Directors.

${ }^{59}$ Section 170 - 173 of the Jordanian Penal Code, 1960.

${ }^{60}$ Section 174 of the Jordanian Penal Code, 1960.

${ }^{61}$ Sections 265 - 70 of the Jordanian Penal Code, 1960.

${ }^{62}$ Section 175 of the Jordanian Penal Code, 1960.

${ }^{63}$ Section 278 of the Jordanian Companies Act, 1997, See also Section 386 (A) of the draft law.

${ }^{64}$ Ibid.

${ }^{65}$ Ibid, Section 289.

${ }^{66}$ Section 42 of the Jordanian Securities Act No. (76) of 2002.

${ }^{67}$ Ibid, Section 56 .

${ }^{68}$ Ibid.

${ }^{69}$ Ibid.
} 
fluencing or attempting to influence the capital market ${ }^{70}$, falsification of statements ${ }^{71}$, offering or selling securities on the basis of false or misleading data ${ }^{72}$, crimes against consumers, economic crimes of price fixing and false advertising ${ }^{73}$, money laundering crimes, bribery and false claims ${ }^{74}$, tax evasion and insider trading crimes, crimes against environment and workers, crimes of pollution, swindles and organized crimes, etc.

Under section 74 (3) of the Jordanian penal Code, there are two types of criminal penalties that can imposed on corporations, including parent companies ${ }^{75}$. The first punishment is a fine, which is applicable to legal entities and natural persons, and the second punishment is a confiscation that is applicable only to corporations ${ }^{76}$. The principle penalties also are applicable to the legal persons and natural persons, but if the principle penalty imposed on corporations, it can be replaced with fines ${ }^{77}$. The penalty of compulsory dissolution of the corporations or parent companies is not covered by section 74 (3) of the Penal code, therefore it can be considered as a criminal penalty, while it can be applied as administrative measure. The same thing is applied in the case of other supplementary measures, such as cessation, temporary receivership and other measures ${ }^{78}$. Those measures are merely administrative measures and not criminal penalties as they are not covered and provided under the Penal Code of Jordan of 1960.

\subsection{Criminal Liability of Parent Company: Comparative Approach}

The study of the subject of criminal liability of parent company for illegal acts and crimes of the subsidiary in common law systems and civil law systems shows several differences. Legal entities, in most of the civil law or common law countries, presently have their own rights and obligations, similar to those rights and obligations enjoyed by human beings. The comparative approach related to the criminal liability of parent company under both common law and civil law jurisdictions shows that most of the common law and civil law countries are more aware about the significance of criminalizing and punishing parent companies for crimes of their subsidiaries, for the benefit of economic and social welfare of the society (Lederman, 1985: pp. 293-294). Hence, the development of the principle of corporate criminal liability in common law and civil law countries resulted in subjection of corporations to the criminal law.

The principle of criminal liability of parent company for crimes of the subsidiary is recognized in most of the countries. Corporations can be criminally held for the crimes committed by their natural persons employed by them and for crimes of agents and contractors outside of the corporation (Diskant, 2008: pp. 133-134). The theory of agency and theory of organism are considered the legal basis to establish corporate criminal liability under both civil and common legal systems (Habibzadeh \& Sharifi, 2013: p. 5857).

In countries, under criminal liability model, parent company can be criminally held liable for crimes of the subsidiary. This can be seen in many countries of civil law jurisdictions, such as France, Syria, Lebanon, Iraq Bahrain, as well as Jordan. In USA and Canada, the criminal liability of parent company for crimes of the subsidiary is recognized, even in case of succession on merger and consolidation ${ }^{79}$. In other countries, under the non-criminal liability model, parent companies and subsidiaries are autonomous subjects of law, and they may have the rights that enjoyed by human-beings (Gerhard, 1998: p. 83). The liability of companies, including parent company is equally existed under the administrative and civil system. This can be seen in many countries such as, Germany, Italy, Algeria, Egypt, Libya and Kuwait, the Ukraine, Luxemburg, Mexico, Greece, Brazil, the Slovak Republic, Sweden, Hungary and Bulgaria. In U.A.E., despite the country follow the criminal liability model, but a parent company cannot be held liable for the acts of its employees and directors, as well as for illegal acts of the subsidiary or independent agents or contractors ${ }^{80}$.

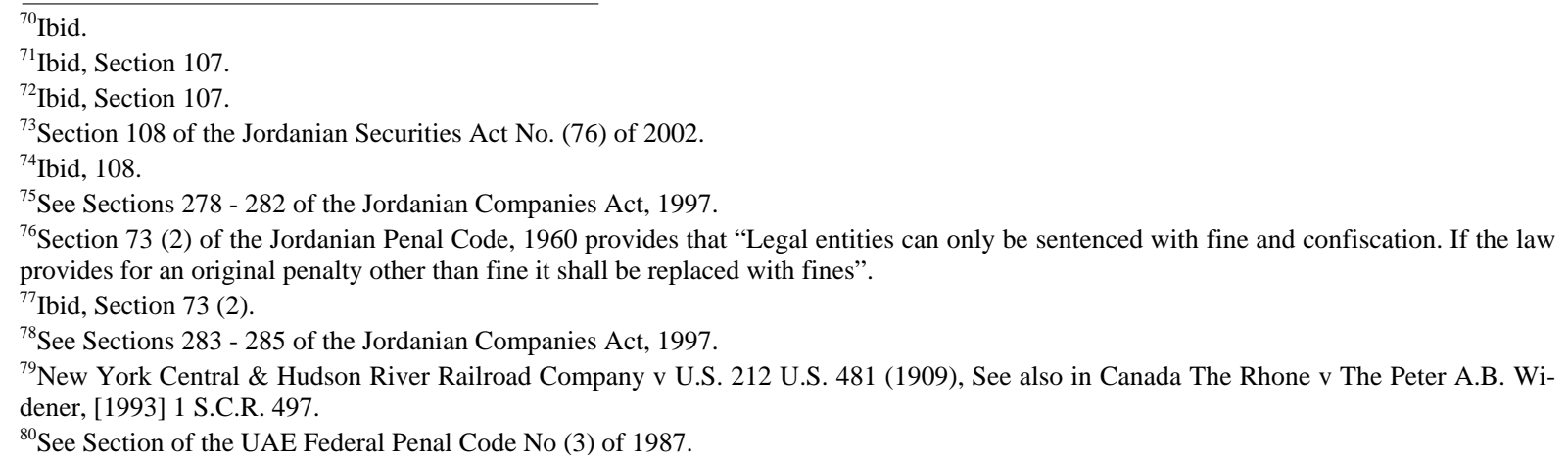


In common law system, several differences are pointed out in both USA and UK, as the corporate criminal liability model in the first is more efficient, while the model is more restrictive in the second. The English model is not similar to the American one, as the later recognizes the criminal liability for all types of legal entities on the grounds of retribution and deterrence, therefore all corporate criminals, including parent company can be held criminally held liable and punished for the crimes of their natural persons or subsidiaries (Wagner, 1999: p. 3).

In Jordan, parent company can be criminally held liable on the basis of the "general liability model”, which makes the liability of parent company similar to that of individuals, in which a parent can be criminally liable for any type of crime committed by its natural persons or subsidiaries within the context of section 73 (2) of the Penal Code, $1960^{81}$. Hence, a parent company can be liable for crimes punishable with original sanctions, which shall be replaced with a fine. This Model is applied in many countries of common law and civil law jurisdictions, such as England, Belgium, Netherlands, U.A.E, Iraq, Bahrain, Syria and Lebanon.

In France, a parent company cannot be criminally liable for any crime of the subsidiary, and it can be only liable for crimes mentioned by the legislator. Accordingly, articles 121 and 122 of the French Penal Code state that legal entities are liable only for crimes provided expressively in the law and regulations (International Commission of Jurists, 2008: p. 56). Moreover, those legal entities are panelized for the frequent involvement in crimes (Fauchald \& Stigen, 2009: pp. 1036-1037). In comparison, the legal system of Jordan makes corporations liable for any crime, and the Jordanian legislator has not neglected the notion that the criminal liability of legal entities, including parent company can be established on the basis of the company's involvement in the commission of the crime as an author or accomplice. Therefore, in contrary to French, a parent company under Jordanian legal system can be convicted for any type of crimes that committed by the subsidiary.

The Jordanian model of corporate liability also differs from the German model. In Jordan, corporations are subject to criminal liability for crimes of their employed natural persons and for illegal acts of the subsidiary, while in Germany, corporations are not subject of criminal liability, but they can be subject of administrative liability for administrative and penal offenses committed by their organs and natural representative (Colwell, 2013). This general rule related to corporate liability in Germany is applied to parent company's liability for illegal acts of the subsidiary (Schiller, 2002). In Jordan, a parent company can be criminally liable for crimes of the subsidiary, when the crime is committed by the agents, representatives or employees that employed by a corporation, and the crime shall be committed in the name or on behalf of the parent or subsidiary company. In contrary, German law requests that a crime has to be linked to the parent corporation or subsidiary's activities in order to establish the corporate administrative liability for such crimes.

Finally, the Jordanian system compared with English, German, and French systems appears more efficient, as it expressively makes all legal entities that can be criminally held liable. Despite the American system is argued an efficient one, but still the Jordanian, German, English, Canadian, Syrian, Lebanon, Iraqi, Bahrain and UAE systems are good models because they make the corporations, including parent companies are criminally liable for all crimes that can be committed by their natural persons.

\section{Corporate Liability Based on Conduct of Parties Outside of Organization}

The concept of corporate criminal liability was recognized by the Jordanian Cassation Court in early sixties of the last century, as the court ruled that the criminal liability can be established against the company as a legal entity $^{82}$. A corporation's managers and its members could not be exempted from the criminal liability for crimes committed it the name of the corporation, and they can be prosecuted and convicted as independent criminal, especially when they commit their crimes intentionally.

It has been clarified by the Cassation Court of Jordan that Section 74 (1) of the Penal Code contains a general rule, which provides that the criminal liability of a person can be held when a crime proved that it was committed consciously and intentionally, and such person can be prosecuted, convicted and punished for such crime. The court explained the legislative attitude towards the concept of corporate liability out of interpretation of section 74 (2) by assuring that the legal entity has its own will and mind, and it can be prosecuted and convicted for its crimes. In another judgment, the Court of Cassation convicted the legal entity for the crime of issuing a check

\footnotetext{
${ }^{81}$ See Section 73 (1) (2) and (3) of the Jordanian Penal Code of 1960.

${ }^{82}$ See Jordanian Court of Cassation, Case No. (31), Cassation Decision, 1961, Journal of Judiciary, p. 42.
} 
without balance in accordance with section 421 of the Jordanian Penal Code ${ }^{83}$.

The aptitude of the Jordanian judiciary toward the concept of corporate criminal liability is clear, as the principle was recognized in the middle of the last century, while the applications of the principle on the parent-subsidiary relationship still has not been tested as it is already done under comparative jurisdiction. As shown earlier, the criminal cases regarding the criminal liability of criminal liability of corporations is enough clear in the legislation and judiciary, but the criminal liability of parent companies are not clear, it is lesser than the civil liability of those companies; therefore courts may rely on the civil law analogous circumstance.

\subsection{Liability for Crimes of Independent Contractors and Agents}

Section 74 (2) of the Jordanian Penal Code, 1960 provides that "legal entities other than governmental, public and official institutions and bodies are criminally liable for crimes committed by their representatives or directors or agents in their name or on their behalf". Thus, according to this section, the legal entity cannot be held criminally liable for offences committed by its employees for reasons of being ultra vires unless those authorized employees were expressly ordered to commit the act in the name of or for the benefit of the corporation. The category of "agent" mentioned paragraph (2) of the same section includes human persons entrusted with certain duties, or authorized to act on behalf of the legal entity and authorized employees of the legal entity (Al Qudah, 2009).

Therefore, contractors and other independent agents, who are entrusted with certain duties of the corporation, or authorized to act on behalf of the legal entity and authorized employees of the legal entity also shall be considered liable persons. The crimes committed by those persons can be attributed to the corporation only when they act in the name of or for the benefit of the corporation and within its scope and purposes.

The legal entity under the conditions referred to in section 74 (2) of the Penal Code, a corporation shall be held accountable for illegal acts committed by the representatives or directors or agents even though criminal proceedings against any of them have been discontinued or the act of indictment rejected. This means, a corporation may be held liable for crimes which have been committed for the benefit of the corporation by its authorized employees or independent contractors and other independent agents who act within the remit or powers (Al Otawer, 2006: p. 362). The criminal liability of corporation referred to in paragraph 2 of this section may also exist where the lack of supervision or control by the human person permitted the commission of crime for the interest of benefit of that corporation by a responsible human actor operating under the supervision and control of the corporate organ.

In Canada, the criminal liability of legal entities for acts of their agents is governed to the rules of Agency, where the agent is defined as a party that has been empowered by another person called the principle. Thus, it has been held that the corporation (principle) can be criminally held liable for acts of its agent fall within the scope of the agent's authority ${ }^{84}$. In civil cases, a corporation can be liable for the wrongful acts of the independent contractors and agents, if they were acting within the scope of their actual, apparent, or usual authority (Friedman, 1996: p. 64). Conventionally, only managers and very senior staffs were deemed fiduciaries. Though, the existing state of the legal rules is that the types of relationships giving rise to fiduciary duties are open ${ }^{85}$.

In USA, legal entities can be criminally held liable for the crimes of independent agents and independent contractors, who act within the scope of agency. Federal courts for deciding the criminal liability of corporations for crimes of their independent agents and contractors distinguishes between two types of strict liability offences and other criminal standers. In several cases, the federal courts in USA decided the criminal liability of corporations for strict offences committed by their independent agents or independent contractors, while the same was not done for other type of offences ${ }^{86}$.

\subsection{Liability Based on Conduct of Employees of Corporate Subsidiaries}

In Jordan, the concept of legal entity includes private law companies, and excludes the public law legal entities for the purposes of criminal liability (Al Otawer, 2006). Section 74 (2) of the Jordanian Penal Code deal with the issue of "directing mind" of the corporation, or the human persons, they are considered as the "alter ego" or

\footnotetext{
${ }^{83}$ See Jordanian Court of Cassation, Case No. (932), Criminal Cassation Decision, 30 November, 2000.

${ }^{84}$ Lloyd v. Grace, Smith \& Co, [1912] A.C. 716 (H.L.) at 736.

${ }^{85}$ LAC Minerals Ltd. v. International Corona Resources Ltd. (1989), 61 D.L.R. (4th) 14 (S.C.C).

${ }^{86}$ See United States v. Parfait Powder Puff Co., 163 F.2d 1008 ( $7^{\text {th }}$ Cri. 1947), see also United States v. Gun, 97 (W.D. Ark.1950).
} 
"soul" of the legal entity, those are human persons including representatives, directors, and employees (Al Sharosh, 2006). For instance, when the holding parent company or its subsidiaries make transactions, or commit crimes, in actuality it is the company agents, representatives or authorized employees who makes all the activities (Al Qudah, 2009). Basically, the holding parent company can be determined guilty for offences of its "ego" persons perpetrated the illegal act and the requested state of mind (Al Shawi, 2002).

\subsubsection{Agency Basis for Parent Company Liability}

According to the agency theory, the natural person who represents the legal entity is its agent (Parisi, 1984: p. 41). Moreover, a corporation has no capacity to act without its representatives, then how the representative can make the contract with himself? This theory is not applied in the term of section 74 of the Jordanian Penal Code because the directors or managers have special authorities specified by the law, where in contrary to the rule an agency they can act against the will of shareholders.

\subsubsection{Organ Basis for Parent Company Liability}

In Jordan, the organic theory is applied as the basis for the relationship between the corporate and its employees. The natural persons, who act within a corporation are its own mind and will, therefore they direct its activities and manage its affairs (Al-Mahazneh, 2015: p. 137). The legal entity is merely an abstraction, has no mind and unable to carry on its own activities without the natural persons (Singh \& Dash, 2016: p. 23). This theory deals with the corporation's employees, agents, officers, representative and managers as the mind and the will of the corporation and incarnates the corporate body (Al Sharosh, 2006; p. 75).

\section{Criminal Liability for Offences of Dissolved Corporations}

In the criminal law of Jordan, the dissolution of a legal entity had the same outcome as the death of human person, abating all litigation in which the legal entity was involved. Although, this rule, it is necessary to establish the criminal liability of the dissolved company. In fact, the subject of criminal legal liability of successor is not covered under the Jordanian Penal Code, especially when the company is dissolved before the initiation or finalization of the criminal proceeding.

\subsection{In Cases of Termination or Change of Status}

In Company Act, the Jordanian legislator has resolved the issue of the liability of legal successor of for the dissolved company's obligations, as the new company is legally obliged under section 238 to bear obligations of merged companies prior to merger (Section 238 of the Company Act, 2006). In criminal matters, the law does not recognize the liability of legal successor for the crimes committed by its predecessor prior to a merger or consolidation, as the provisions of section 74 of the Jordanian Penal Code are incapable of dealing with this subject.

The basic premise of the application of section 74 (2) of the Penal Code is committing the crime in the name of or for the benefit of the company by its authorized employees, which cannot be applied to the case of the legal successor because the crimes are committed by employees of the predecessor company. Therefore, it does not matter under Jordanian Penal Code for deciding the criminal liability of the legal successor for crimes of the dissolved company, whether the company has been dissolved before or after the criminal proceedings are finalized, and then no penalties or security measures or fins can be imposed on the new company as a legal successor of the predecessor company.

\subsection{In Cases of Bankruptcy}

Section 74 (2) of the Jordanian Penal Code is applicable to the crimes committed before the instigation of or in the course of the bankruptcy procedure, and the bankrupted legal entity shall be criminally liable for those crimes. The punishment of fine and confiscation shall be imposed against the liable legal entity referred to in paragraph 3 of section 74 of the Penal Code.

The criminal liability of the liquidated legal entity committed before the instigation of or in the course of the bankruptcy procedure is not explained under the Penal Code, while the employees who committed those crimes can be held personally liable. 
In Jordan, the successor may not be held criminally liable for the crimes of the dissolved company and any seizure, security measures or fines can be imposed on the successor. Section 74 of the Jordanian Penal Code is not applied to the offences committed by the employees of the dissolved corporation, as the language used in this section is very general and suitable for establishing of corporate criminal liability for the acts of its employees itself.

In USA, the same rule adopted under Jordanian criminal law is applied by Federal laws, but the United Sates Supreme Court has developed a rule says that the dissolved corporation could incur criminal liability ${ }^{87}$, and it emphasized that there is no difference between the civil and criminal liability on the issue of a dissolved corporation $^{88}$. The criminal liability of the successor corporation for the crimes of its predecessor is recognized by judiciary in USA, it has been classified by one of the American courts that "an existing corporation. (cannot escape) criminal liability for past acts simply by discarding its offending element by a transfer of assets”, ${ }^{\text {" In the }}$ course of applying the criminal liability doctrine for the illegal acts of the dissolved companies, the question remains here whether to apply this doctrine on the merged company or the surviving company for the acts of the dissolved company ${ }^{90}$.

\section{Criminal Liability for Offences of Predecessors Corporations}

\subsection{Successor and Affiliate Criminal Liability}

The criminal liability of corporations for the acts of its human persons is recognized under the Jordanian Penal Code, but the question here is about under what circumstance the parent company can be held liable for criminal acts of its subsidiaries, especially in the case of a predecessor or affiliate company. The corporation may be also held liable for the same crime once it is provided that the criminal act was committed within corporation's scope and in its name and for its benefit ${ }^{91}$.

The parent company can be criminally held liable for the crimes of its subsidiary, especially if the subsidiary is wholly owned by the parent company. The Jordanian Cassation Court ruled that the liability can be imputed to the company as actions of custom evasion of any other agent can be attributed to the company on the basis of section 205 of the Custom Act and section 74 of the Penal Code, $1960^{92}$.

Similarly, the court in USA recognized the criminal liability of the parent company for illegal and criminal acts of its subsidiary, as in one of the following cases (O’Reilly, Hanlon, Hall, Jackson, \& Lewis, 2009: p. 26):

1) The corporate existence of the subsidiaries apart from the parent was mere form and the agents of the subsidiaries acted as agents for the parent, all of the corporations being one unitary enterprise, or

2) The subsidiaries were agents of the parent, and the employees of the subsidiaries acted as subagents of the parent corporation $^{93}$.

According to O’Reilly, the analysis made by the court in the above mentioned cases is similar to "piercing the corporate veil” in the civil context (O’Reilly, Hanlon, Hall, Jackson, \& Lewis, 2009: p. 26).

\subsection{Liability for Offences of Constituent Corporations in Mergers and Consolidations}

In Jordan, the criminal liability of a successor company for acts of its predecessor prior to a merger or consolidation is vague. The successor company can be held for the criminal acts of its predecessor on the basis of theory of "directing mind or will” of the corporation, but may be only for crimes committed by the predecessor after a merger or consolidation (Paul, 1987: p. 652). The criminal liability of the successor corporation under section 74 (2) is not clear especially for the crimes of the predecessor that committed before a merger or consolidation $^{94}$, unless the criminal investigation with the predecessor has not completed before a merger or consolidation.

\footnotetext{
${ }^{87}$ Melrose Distillers, Inc. v. United States, 359 U.S. 271 (1959).

${ }^{88}$ Ibidat 274.

${ }^{89}$ United States v. Ashland Oil, Inc., 537 F. Supp.427, 432 (M.D. Tenn. 1982).

${ }^{90}$ United States v. Michigan Carton Co, 552 F.2d 198, 201 (7th Cir. 1977).

${ }^{91}$ See Jordanian Court of Cassation, Case No. (31), Cassation Decision, 1961, Journal of Judiciary, p. 421.

${ }^{92}$ See Jordanian Court of Cassation, Case No. (1091), Criminal Cassation Decision, 11 November, 2007.

${ }^{93}$ Compare Nat. Dairy Prods. Corp. v United States, 350 F.2d 321,327 (8 ${ }^{\text {th }}$ Cir.1965).

${ }^{94}$ For the purposes of this section the directing mind of a corporation is a human person in charge with designing and supervising the implementation of the parent company policy, including representatives and directors and authorized agents who act within their scope of delegated authority.
} 
Thus, the criminal liability of a successor for the acts of its representatives and organs of the predecessor can be established only after proving the liability of those natural persons that occurred after a merger or consolidation (Hind, 1997: p. 82). This means the successor company may be held liable for the criminal acts of its predecessor on the basis that all activities of the predecessor after a merger or consolidation fall within the general aims of the successor company itself. For this reason if the predecessor carried fraudulent or improper activities, the successor will be investigated and prosecuted as such activities made by it, as they fall within its general aims. Under the Jordanian Companies Act, 1997 it is clearly stated that one of the aims of a parent company is to manage its subsidiaries (Abdel Tawab, 1990: p. 338).

\subsection{Liability of Successor Companies for Offences of Acquired Firms}

A company cannot be held liable under the Jordanian Penal Code for the crimes committed by a company it acquires, unless if those crimes occurred after the acquisition and even if they were not entirely known to the acquiring company (Al Otawer, 2006: p. 357). The concept of successor criminal liability has not been generally accepted in the Jordanian criminal prosecutions, as section 74 (2) of the Jordanian Penal Code deals only with the subject of corporate criminal liability for the acts of the corporation's employees (Al Masada, 2014: p. 115). Court cases supporting such liability has, so far, usually been limited to the civil and commercial law context where the bad actor has simply transformed itself into a new corporate entity as provided in section 238 of the Company Act, $2006^{95}$.

In criminal law, the successor company has separate and independent legal personality form the acquired company, for this the successor cannot be criminally held liable for acts of its acquired firm, because criminal law aims to punish bad actors, on the basis of the Mens Rea requirement, and therefore the successor company, like human persons, should not be held criminally liable for crimes of others who act independently. In contrary, the successor can be held liable for the obligations and acts of the acquired company as provided in section 238 .

\subsection{Liability of Companies Based on Acquisition of Stock Corporate Offenders}

Criminal liability of the acquiring company cannot be imposed merely for the acquisition of the stock of the acquired firm, and the new owner is not liable for the crimes of the corporation which has acquired its stocks. Hence, for instance, if the parent company acquires the stock of a subsidiary company and upholds the new company as its subsidiary, the parent company, in this case, should not be held criminally liable for illegal and criminal acts that committed in the name or on behalf of the acquired subsidiary.

According to sections 238 and 239 of the Jordanian Company Act, 2006, the acquiring company is legally liable for the obligations resulted from the acquisition of its subsidiary's stocks. In criminal law, section 74 of the Jordanian Penal Code does not cover this subject and brings no solution for this issue. The application of the provisions of section 74 literally sounds that the parent company cannot be criminally liable for the previously committed acts of its subsidiary's employees as they are not part of the parent company ego. Therefore, the liability of the subsidiary may continue although the revolutionizing in ownership, that way decreasing the value of the ownership interest that the acquiring firm has in the acquired or subsidiary company.

\subsection{Liability of Companies Based on Acquisition of Assets of Corporate Offenders}

In general, the criminal acts of the corporation's employees are not attributed to the corporation unless those acts were committed in the name or behalf of the corporation. This is the situation under section 74 (2) of the Jordanian Penal Code Parent, which means that the acquiring company may not be criminally liable for the illegal acts of a transferring company solely due to the asset-purchase agreement or on the basis of acquisition of the assets of acquired company.

This principle is known in civil cases, but still is applicable in criminal cases with taking into consideration some of the exceptions made to this general principle such as the approval of the acquiring company to bear the criminal liabilities of the acquired company, also the agreement of an asset purchase should be a de facto merger

\footnotetext{
${ }^{95}$ Section 238 of the Jordanian Company Act, 2006 provides that: “All the rights and obligations of merged companies shall by operation of law be transferred to the merging company or the company resulting from the merger, after the completion of merging procedures and registering the company in pursuance to the provisions of this Law. The merging company or the one resulting from the merger shall be considered a legal successor to the merged companies and shall legally replace them in all their rights and obligations”.
} 
and the transaction must be fraudulent. In civil cases, it is provided in section 239 of the Jordanian Company Act, 2006 that the merging company can be liable for damages caused by the merged company to others, but still has the right to claim what it has paid from the authorized persons or employees of the emerging company who shall also be subject to the penalties ${ }^{96}$.

\section{Conclusion}

\subsection{A Summary Characterisation}

The corporate criminal liability is an integral part of Jordanian Penal Code No (16) of 1960, and the general rules of this law record the lead and progress timeline on its counterpart the French Penal Code of 1992 that recognized the CCL after decades of refusal and hesitation. There is a consensus in the legal systems of both civil law and common law, each the parent company and the subsidiary have its own separate legal personality. In Jordan, the legal entities are entitled to commit any type of offences and can be held criminally liable for all crimes. The parent company controlling over its subsidiaries is the keystone of its legal liability for the acts and offences of the subsidiary, as the parent is considered as a manager of the subsidiary and a principle shareholder in the subsidiary's capital. Moreover, parent company controls the subsidiary's board of directors and decisions, by which the parent can elect and dismiss its members. This means that the general rule of corporate criminal liability of section 74 (3) of the Jordanian Penal Code is applied on parent companies.

In the UK, corporations are directly liable for their illegal actions, as it adopts the directing mind principle where directing minds are considered as the corporation. This principle states that liability for acts and mental states of the corporate employees and officers can be attributed to a corporation on the basis that they are the directing principle of a corporation. The independent legal personality of the corporation is recognized under British legal system, and thus the parent company has its own directing mind and the subsidiary also has its own legal personality, and no one can be criminally liable for illegal actions of others. In contrary, the USA legal system laid down the vicarious liability, where a corporation can be criminally held liable for the illegal acts of its employees and the employees of its subsidiary.

In Canada, the position is described by the datum that the directing mind principle can be founded at a higher level of the legal entity. The legal personality of the parent company is separated from the subsidiary, and the parent cannot be held liable for the illegal acts of the subsidiary except in the availability of the circumstances mentioned in section 21 of the Criminal Code or on the basis of the doctrine of "Pierce of the corporal veil".

In France, the corporate criminal liability is recognized under the New Code of Penal of 1992; therefore corporations can be criminally held liable for the illegal acts of its legal representatives. The corporate criminal liability can be established on the basis "delegation of powers" and on the "negligence" of a corporation, despite the parent company and the subsidiary have autonomous legal personalities, the parent company can be held criminally liable for the illegal acts of the subsidiary on the basis of the "intervention” with the subsidiary's affairs.

The situation in Germany and Italy is different, as the German and Italian legal systems developed administrative sanctions regime that embodies legal rules on corporate criminal liability, but the efforts for bringing the corporate liability to the scope of criminal law are going on. Presently, parent companies cannot be held criminally liable for the illegal acts of the subsidiary because the lack of capacity to act and to will, and both the parent and the subsidiary are not capable of being criminally liable and cannot undergo criminal penalty.

In comparison, the Jordanian legislation recognizes the double criminal responsibility of both the legal entity and the individuals employed by the corporation, the same is applied by many other common law and civil law systems such as such as France, Syria, Lebanon, Iraq Bahrain, as well as USA and Canada. Moreover, the parent company is a legal entity, and has no self-capacity to express its will unless through its natural persons, whose represent it in the management of its subsidiary. Hence, upon its shares that owned in the capital of its subsidiary that enable it to elect human persons to represent its interests in the subsidiary's board of directors, therefore it is entirely responsible for the acts and offences committed by the subsidiary company. The parent company controls the management and financial affairs of its subsidiary automatically by hold more than 51\% of the subsidi-

\footnotetext{
${ }^{96}$ Section 239 of the Jordanian Company Act, 2006 provides that: "Should liabilities or claims appear after the final merger on one of the merged companies, and should they have been hidden by some authorized persons or employees in the company, then these liabilities or claims shall be paid to the creditors by the merging company or by the company resulting from the merger who shall both have the right to claim what they paid from those authorized persons or employees who shall also be subject to the penalties for that act by the laws in force".
} 
ary's stokes, sections 205 and 206 of the Jordanian Company Act makes it clearly that the management of subsidiary must be one of the principles duties of the holding parent company. The parent company and its subsidary has an economic and financial unity, as the parent is responsible for financial affairs of the susidary, especially when the subsidiary as wholly owned by the parent. Moreover, the items of the annual budget of the parent company consist of the financial accounts of both the parent company and its subsidiaries. The criminal liability of parent companies for illegal acts of the subsidiary is not treated deeply under both Jordanian Penal Code and the Companies Act, and the main reason behind that is this type of companies is introduced newly to the Jordanian legal system and still under trial, this may affect the increasing role of these companies' within the business and investment environment in Jordan.

The absence of a special corporate criminal procedures law in Jordan, as corporations are investigated and tried by the general procedures that designed for human persons, while other countries have enacted special corporate criminal procedures, such as France for example. A parent company and its subsidiaries are one project and should not be considered as independent legal entities separated from each other, to avoid the legal tribulations which could result from this phenomenon. In contrary to USA, the criminal liability of the legal successor for crimes of the dissolved legal entity and the acquired company that committed prior to consolidation does not exist under the Jordanian Penal Code, and the criminal liability of acquiring company for the acquisition of assets of an acquired company is not fixed under the Jordanian Penal Code, as well as the same liability of parent companies for acquisition of stock corporate offenders is not treated by the Jordanian traditional criminal law. In contrary to the corporate sentencing systems of some of common law and civil law countries, corporate sentencing system in Jordan is limited and simple, as the only penalties that can be imposed on corporations under section 74 (3) of the Penal Code are fines and confiscation.

\subsection{Suggested Reforms to the Relevant Legislation in Jordan}

Comprehensive reforms are suggested under Jordanian Companies Act and Penal Code, as the following:

- Section 74 of the Jordanian Penal Code must be amended and the criminal liability of parent company for illegal acts of the subsidiary must be deeply covered, as well as the corporate sentencing system must contain serious penalties for corporate crimes to prevent corporations, parent corporations and subsidiaries from committing crimes.

- Sections 204 - 208 of the Jordanian Companies Act must be amended in order to stipulate the unity and not independency of the legal personalities of both parent company and its subsidiary.

- New specific sections in Penal Code must be enacted to cover the criminal liability of the successor for the crimes that committed by the dissolved legal entity and the acquired company prior to merger or consolidation. In the same context, new changes must be made to the Companies act in order to clarify the relationship between the successor with both the dissolved legal entity and the acquired company.

- The Criminal Procedures Code must be amended for the purpose of crating new and special procedural system that suitable for prosecuting corporations, including parent company for its crimes and the crimes of its subsidiaries.

\subsection{Brief Justifications for Changes}

The proof of criminal liability of parent companies for illegal acts of their subsidiaries is not an easy, as there are real barriers for investigative and prospective agencies to enforce it. The primary problematic factor is the lack of a systematic enforcement of criminal justice administration, for this reason civil litigation is seen as an effective alternative for law enforcement. The difficulty of detecting the crimes of parent companies and the subsidiaries makes investigators resort to the help of these companies for assistance and this encourage the parent to escape from criminal liability.

In Jordan, there is a real need for appropriate legislative reforms to clearly specify liability and sanctions of the parent company for illegal acts of its subsidiary. Moreover, the experience of the comparative legal systems in dealing with corporate crimes is very useful, as they adopted primary regulatory bodies to tighten their legislations. The Cassation Court of Jordan may play a potential role in future that influence parent companies to found and implement policies that preclude their subsidiaries from committing illegal acts. Hence, the above suggested reforms to the relevant legislation in Jordan can be justified as the following:

- The amendment of section 74 (2) of the Jordanian Penal Code allows the prosecution of the parent company 
for crimes of the subsidiary, and particularly the criminal liability shall be based not only upon the commission of the crime by individuals of the corporation, but also on the negligence and lack of caring of the corporation. Moreover, the most importantly prosecution of the subsidiary's individuals liable for the illegal acts and offences is considered the best device for retribution that must be taken in to account.

- The current penalties prescribed for companies under section 74 (3) of the Penal Code does not deter and prevent parent companies and their subsidiaries from committing illegal businesses, and therefore there is a real need to make those penalties harsher, as they have deterrent effect and may minimize parent-subsidiary crimes. Therefore, huge fines must be imposed on the parent corporation irrespective of the view says that such penalty may affect innocent stockholders, but the fact the majority of shareholders, directors, managers and employees are usually involved in the wrongdoing. Moreover, another sanction can be introduced to section 74 (3) is forcing the parent company to surrender the illegal gains out of the committed crime.

- The amendment of sections 204 - 208 of the Jordanian Companies Act is very useful for confrontation of the financial, economic and environmental crimes of the parent company and the subsidiary. Jordanian legislation recognized the principle of separation of the legal personalities of both the parent company and the subsidiary. The reforms of those sections contribute to more explanation on the relationship between the parent company and the subsidiary, by insisting that both the parent company and its subsidiary have one legal personality. Hence, such change will prevent the parent company to escape the criminal liability for illegal acts of the subsidiary.

- The successor company shall be criminally liable for crimes of the dissolved legal entity and the acquired company that committed prior to merger or consolidation, especially when the successor company runs the same management and shareholders or owners and business, as well as the liability of the acquiring company for the acquisition of assets of an acquired company is not specified under the current law.

- The crimes of subsidiaries are mostly of a financial and economic nature, which requires a change in the organic structure of a public prosecution agency through appointing economic specialists in this agency. The economic investigator's role will be more vital during the criminal investigation with the parent company. Consequently, adopting special corporate criminal procedures is useful criminal justice as well as for corporations in order to prevent the delay of corporate justice, which may be very costly for corporations themselves and for the national economy.

\section{References}

Abdel Tawab, M. (1990). The New of Commercial Judiciary: Commercial Judgments of the Court of Cassation in Fifteen Years (1975-1990), Cairo, Egypt. (In Arabic)

Al Ibrahim, M. (2007). The Nature of the Legal Relationship between the Holding Company and Its Subsidiary. Almanarh Journal, Al-Bayt University, 13, 73-17.

Al Masada, A. M. (2014). The Relationship between Holding Company and Its Subsidiaries: Comparative Study. The Journal of Academy for Social and Humanitarian Studies, 12, 115. (In Arabic)

Al Otawer, R. I. S. (2006). Criminal Liability of the Legal Person. Damascus University Journal of Economic and Legal Sciences, 22, 341-381. (In Arabic)

Al Qudah, M. (2009). Corporate Criminal Liability under the Criminal Laws of Jordan and Australia: A Comparative Analysis. Journal of Shari'a and Law, United Arab Emirates University, 37, 27-88.

Al Sharosh, M. A. S. (2006). The Criminal Liability of Legal Entities. Master Dissertation, Mu’tah: Mutah University. (In Arabic)

Al Shawi, A. H. (2002). The General Principles of Penal Law. Kuwait: Al. Resala Printing.

Aldik, K. (2016). The Criminal Liability of Legal Entity: Comparative Study. Journal of Law and Business, University of Al. Hassan, 5, 3-13.

Al-Mahazneh, M. (2015). The Criminal Responsibility of the Legal Person in the Case of Absence Representative Characterization to the Member Who Committed the Crime: Comparative Study. Dirasat: Journal of Law and Sharai. The Deanship of Academic Research, University of Jordan, 42, 133-146.

An Association of Independent Accounting Firms (2015). Permanent Establishment in Romania: Branch or Subsidiary? http://www.afigec.com/data/en/pdf/212/Romania---Permanent-Establishment.pdf?utm_content=buffer39fc0\&utm_mediu $\underline{\mathrm{m}=\text { social\&utm_source=twitter.com\&utm_campaign=buffer }}$

Augustus, M. K., \& Erlinda, S. E. (2009). Holding Companies: A Structure for Managing Diversification. Philippine Man- 
agement Review, 16, 1-12.

Ayadhi, I. B. M. (2015). The Relationship between the Holding Company and Its Subsidiary and Its Impact on Zakat. SABIC Program for the Study of Islamic Financial Markets, Riyadh: The Islamic University of Imam Muhammad Bin Saud, Kingdom of Saudi Arabia, Ethiopia.

Ayalew, A. (1998). Criminal Liability of Bodies Corporate. Senior Thesis, Addis Ababa: Faculty of Law, Addis Ababa University.

Binning, C. (2015). The Changing Face of Corporate Criminal Liability. http://www.lexology.com/library/detail.aspx?g=8f122788-b32d-4d99-9bb0-0d8b1c36db5c

Bonbright, J. C., \& Means, G. C. (1969). The Holding Company. New York.

Bose, M. (2011). Corporate Criminal Liability in Germany, the Series Ius Gentium. Comparative Perspectives on Law and Justice, 9, 227-228.

Burke, M. J. (1992). Use of the Delaware Investment Holding Company for Intellectual Property Assets. Master Dissertation, United States: University of New Hampshire, Franklin Pierce Law Center.

Carla, M. (2010). The Introduction of Corporate “Criminal” Liability in Italy. http://esameavvocato.diritto.it/docs/30795-the-introduction-of-corporate-criminal-liability-in-italy

Catargiu, M. (2013). The Origins of Criminal Liability of Legal Persons: A Comparative Perspective. AGORA International Journal of Juridical Sciences, No. 3, 26-30.

Celia, W. (2002). The Reform of Corporate Criminal Liability. The Reform of UK Company Law. London: Cavendish.

Chella, J. (2012). The Complicity of Multinational Corporations in International Crimes: An Examination of Principles. Ph.D. Thesis, Gold Coast: Law Faculty, Bond University.

Chertier, B. J. (2015). The Case for Subsidiary Corporate Governance. http://cgs.computershare.com

Clapham, A. (2008). Extending International Criminal Law beyond the Individual to Corporations and Armed Opposition Groups. Journal of International Criminal Justice, 6, 899-926. http://dx.doi.org/10.1093/jicj/mqn076

Colwell, G. (2013). Criminal Bribery and Corruption Liability of Companies under German Law. http://www.anticorruptionblog.com/germany/criminal-bribery-and-corruption-liability-of-companies-under-german-law/

Cugia di Sant'Orsola, F., \& Giampaolo, S. (2011). Liability of Entities in Italy: Was It Not Societas Delinquere Non Potest? New Journal of European Criminal Law, 2, 59-74.

De Maglie, C. (2005). Models of Corporate Criminal Liability in Comparative Law. Washington University Global Studies Law Review, 4, 547. http://openscholarship.wustl.edu/law_globalstudies/vol4/iss3/4

Deckert, K. (2011). Corporate Criminal Liability in France, the Series IusGentium. Comparative Perspectives on Law and Justice, 9, 147-176.

Diskant, E. B. (2008). Comparative Corporate Criminal Liability: Exploring the Uniquely American Doctrine through Comparative Criminal Procedure. The Yale Law Journal, 118, 126-176. http://dx.doi.org/10.2307/20454705

Doyle, C. (2013). Corporate Criminal Liability: An Overview of Federal Law. Congressional Research Service. https://www.fas.org/sgp/crs/misc/R43293.pdf

Dubber, M. D. (2012). The Comparative History and Theory of Corporate Criminal Liability. http://papers.ssrn.com/sol3/papers.cfm?abstract_id=2114300

European Commission (2012). Guidelines on Eligibility Conditions for an AEO and the Procedure to Be Followed in Case of Multinational Companies and Large Businesses (2nd ed.). Brussels, Belgium: Author.

Farrar, J. H. (1987). Ownership and Control of Listed Public Companies: Revising or Rejecting the Concept of Control. In B. G. Pettet (Ed.), Company Law in Change (pp. 39-67). London: Stevens \& Sons.

Fauchald, O. K., \& Stigen, J. (2009). Corporate Responsibility before International Institutions. The George Washington International Review, 40, 1025-1100.

Fischer, P. (1985). Transnational Enterprises. In R. Bernhardt (Ed.), Encyclopedia of Public International Law (Vol. 7, p. 515). Amsterdam: North Holland Publishing Company. http://dx.doi.org/10.1016/b978-0-444-87911-0.50130-6

Friedman (1996). Law of Agency (7th ed.). Toronto: Butterworth.

Gajewski, D. (2012). The Holding Company as an Instrument of Companies’ Tax-Financial Policy Formation. Journal of Contemporary Economics, 7, 75-82. http://dx.doi.org/10.5709/ce.1897-9254.75

Gerhard, F. (1998). National Development in Germany: An Overview. In A. Eser, G. Heine, \& B. Huber (Eds.), International Colloquium on Criminal Responsibility of Legal and Collective Entities (pp. 83-88). Germany: Max Planck Institute for Foreign and International Criminal Law.

Gibson, A., \& Fraser, D. (2011). Business Law (5th ed.). New York: Pearson. 
Grimes, J., Niblock, R., \& Madden, L. (2013). Corporate Criminal Liability in the UK: The Introduction of Deferred Prosecution Agreements, Proposals for further Change, and the Consequences for Officers and Senior Managers. https://www.kingsleynapley.co.uk/news-and-events/news/corporate-criminal-liability-in-the-uk-deferred-prosecution-agre ements

Habibzadeh, M., \& Sharifi, M. (2013). Imposing Criminal Liability to Corporate Bodies. International Journal of Innovative Research in Science, Engineering and Technology, 2, 5855.

Hahlo, H. R. (1969). Company Law through the Cases: A Collection of Leading English and South African Cases on Company Law Together with Explanatory Notes and Comments (2nd ed.). South Africa: Juta \& Company Ltd.

Hind, H. M. (1997). The Extension of the Parent Company's Liability for the Debts of its Fledgling Company in Group of Corporations, with Particular Reference to the Multinational Companies. Ph.D. Thesis, Cairo: Ain Shams University.

Hudson, S. (2016). The Relationship between a Company and Its Subsidiary. http://smallbusiness.chron.com/relationship-between-company-its-subsidiary-14696.html

Huston, J., \& Edwards, J. (2013). Relationships between Parent and Subsidiary Corporations: Implications for Litigation. http://www.acc.com/chapters/sandiego/upload/Relationships-Between-Parent-and-Subsidiary-Corporations-Implications-f or-Litigation.pdf

International Commission of Jurists (2008). Corporate Complicity \& Legal Accountability: Criminal Law and International Crimes (Vol. 2). Report of the International Commission of Jurists Expert Legal Penal on Corporation Complicity in International Crimes, Geneva, Switzerland.

Ismail, M. (1990). The Holding Company and Its Relationship with Its Subsidiaries. Mu'tah: Mutah University. (In Arabic)

Kazim, A. (2007). The Nature of the Holding Company-Subsidiary Company Relationship. Journal of Legal Sciences, University of Bagdad, 22, 30. (In Arabic)

Kerr, T., Ogiba, C., \& Robinson, T. (2014). Behind the Veil and the Blurred Distinction of Entity Liability.

http://www.mvalaw.com/news-publications-342.html

Koessler, M. (1949). The Person in Imagination or Persona Ficta of the Corporation. Louisiana Law Review, 9, 435-449.

Kukharchuk, M. (2008). The Relationship between a Parent Company and Its Subsidiary: Does the Family Stick Together? A Comparison of U.S., English and Czech Rules on the Parent-Daughter Companies' Relationships. The Common Law Review, No. 9, 9-14.

Latimer, P. (2011). Australian Business Law (30th ed.). Sydney: CCH Australia Limited.

Lazarus, A. A. (2001). Multinational Corporations. International Encyclopedia of the Social \& Behavioral Sciences.

Lederman, E. (1985). Criminal Law, Perpetrator and Corporation: Rethinking a Complex Triangle. The Journal of Criminal Law and Criminology, 76, 285-340. http://dx.doi.org/10.2307/1143611

Lederman, E. (2000). Models for Imposing Corporate Criminal Liability: From Adaptation and Imitation toward Aggregation and the Search for Self-Identity. Buffalo Criminal Law Review, 4, 641-708. http://dx.doi.org/10.1525/nclr.2000.4.1.641

Legum, B. (2005). Defining Investment and Investor: Who Is Entitled to Claim? Symposium on Making the Most of International Investment Agreements: A Common Agenda. Paris.

https://www.oecd.org/investment/internationalinvestmentagreements/36370461.pdf

Muhammady, M. S. (2000). Introduction to Companies. Da’ar Al. Yosr for Publication.

O’Mahony, N. (2004). German-Irish Corporate Relationships: The Cultural Dimension Peter Lang AG (pp. 112-115). Hochfeldstrasse: European Academic Publisher.

O’Reilly, J. T., Hanlon, J. P., Hall, R. F., Jackson, S. L., \& Lewis, E. (2009). Punishing Corporate Crime: Legal Penalties for Criminal and Regulatory Violations. New York: Oxford University Press, Inc.

Parisi, N. (1984). Theories of Corporate Criminal Liability (Or Corporations Don't Commit Crimes, People Commit Crimes). In H. Hochstedler (Ed.), Corporations as Criminals-Perspectives in Criminal Justice 6 (pp. 41-68). New York: Sage Publications.

Paul, H. W. (1987). Principles of Accounting (4th ed.). Florida City, FL: Harcourt Brace Publisher.

Pleasant, D. B. (2013). Using the Single-Enterprise Doctrine to Hold Sister Corporations Liable. http://www.plaintiffmagazine.com/Aug13/Pleasant_Using-the-Single-Enterprise-Doctrine-to-hold-sister-corporations-liabl e_Plaintiff-article.pdf

Prakash, A., \& Griffin, J. J. (2012). Corporate Responsibility, Multinational Corporations, and Nation States: An Introduction. Business and Politics, 14, 1-10. http://dx.doi.org/10.1515/bap-2012-0014

Ramsay, I. M. (1994). Holding Company Liability for the Debts of an Insolvent Subsidiary: A Law and Economics Perspective. University of New South Wales Law Journal, 17, 520-545. 
Roby, I. C. (2013). Corporate Criminal Liability. How Can International Crimes Be Attributed to a Corporation? A Published Research Paper, Amsterdam: University of Amsterdam.

Schiller, C. (2002). Civil and Criminal Liability of Managing Directors in Insolvency. http://www.internationallawoffice.com/Newsletters/Insolvency-Restructuring/Germany/Schultze-Braun/Civil-and-Crimina l-Liability-of-Managing-Directors-in-Insolvency

Singh, S., \& Dash, L. (2016). Criminal Liability of Corporations. IOSR Journal of Humanities and Social Science (IOSRJHSS), 21, 22-27.

Spencer, R. (2004). Corporate Law and Structures: Exposing the Roots of the Problem. https://corporatewatch.org/sites/default/files/corporate_structures.pdf

Szumański, A. (1996). Legal Regulation of the Holding in the Polish and European Company Law: Conceptual Issues. Commercial Law Review (Przegląd Prawa Handlowego), 8, 39-48.

Tigar, M. E. (1990). It Does the Crime But Not the Time: Corporate Criminal Liability in Federal Law. American Journal of Criminal Law, 17, 211.

Wanger, M. (1999). Corporate Criminal Liability National and International Responses, International Society for the Reform of Criminal Law 13th International Conference Commercial and Financial Fraud: A Comparative Perspective. Malta: The International Centre for Criminal Law Reform and Criminal Justice Policy.

Weissmann, A., Ziegler, R., McLoughlin, L., \& McFadden, J. (2008). Reforming Corporate Criminal Liability to Promote Responsible Corporate Behavior. The US Chamber Institute for Legal Reform. http://www.instituteforlegalreform.com/uploads/sites/1/WeissmannPaper.pdf

Werlauff, E. (2003). EU Company Law (2nd ed.). DJOF.

Wymeersch, E. (2003). Do We Need a Law on Group of Companies. In K. Hopt, \& E. Wymeersch (Eds.), Capital Markets and Company Law (pp. 575-579). New York: Oxford University Press Inc.

Accepting pre-submission inquiries through Email, Facebook, LinkedIn, Twitter, etc.

A wide selection of journals (inclusive of 9 subjects, more than 200 journals)

Providing 24-hour high-quality service

User-friendly online submission system

Fair and swift peer-review system

Efficient typesetting and proofreading procedure

Display of the result of downloads and visits, as well as the number of cited articles

Maximum dissemination of your research work

Submit your manuscript at: http://papersubmission.scirp.org/ 